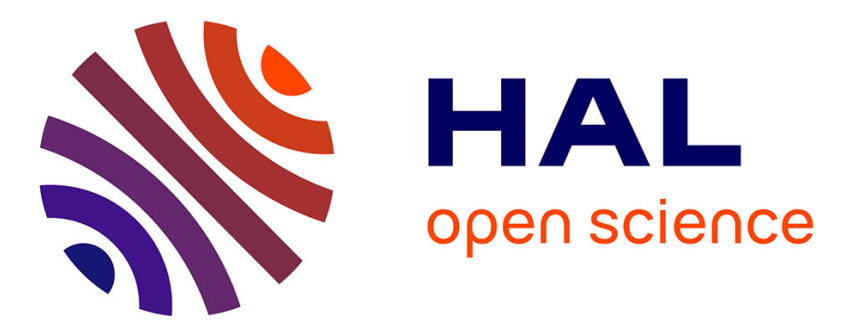

\title{
Multiple sulfur isotopes signature of Thermochemical Sulfate Reduction (TSR): Insights from Alpine Triassic evaporites
}

Guillaume Barré, Émilie Thomassot, Raymond Michels, Pierre Cartigny, Pierre Strzerzynski, Laurent Truche

\section{To cite this version:}

Guillaume Barré, Émilie Thomassot, Raymond Michels, Pierre Cartigny, Pierre Strzerzynski, et al.. Multiple sulfur isotopes signature of Thermochemical Sulfate Reduction (TSR): Insights from Alpine Triassic evaporites. Earth and Planetary Science Letters, 2021, 576, pp.117231. 10.1016/j.epsl.2021.117231 . hal-03396230

\section{HAL Id: hal-03396230 \\ https://hal.science/hal-03396230}

Submitted on 26 Oct 2021

HAL is a multi-disciplinary open access archive for the deposit and dissemination of scientific research documents, whether they are published or not. The documents may come from teaching and research institutions in France or abroad, or from public or private research centers.
L'archive ouverte pluridisciplinaire HAL, est destinée au dépôt et à la diffusion de documents scientifiques de niveau recherche, publiés ou non, émanant des établissements d'enseignement et de recherche français ou étrangers, des laboratoires publics ou privés. 


\section{Multiple sulfur isotopes signature of Thermochemical Sulfate}

2

3 Guillaume Barré ${ }^{*}$, Émilie Thomassot ${ }^{2}$, Raymond Michels ${ }^{1}$, Pierre Cartigny ${ }^{3}$, Pierre

4 Strzerzynski ${ }^{4}$, Laurent Truche ${ }^{1,5}$

$5 \quad{ }^{1}$ Université de Lorraine, CNRS, GeoRessources, UMR 7359, BP 70239, F-54506 Vandouvre-

6 lès-Nancy, France

7

${ }^{2}$ Université de Lorraine, CNRS, UMR 7358, CRPG, Vandœuvre-lès-Nancy, France

${ }^{3}$ Université de Paris, Institut de physique du globe de Paris, CNRS, F-75005 Paris, France

${ }^{4}$ Laboratoire de Géologie UFR Sciences et Technique, Université du Mans, Avenue O. Messiaen, 72000 Le Mans, France

${ }^{5}$ Univ. Grenoble Alpes, Univ. Savoie Mont Blanc, CNRS, IRD, IFSTTAR, ISTerre, 38000 Grenoble, France.

*e-mail: guillaume.barre.2@ulaval.ca

*Present address: Département de géologie et génie géologique, centre E4M, Université Laval, Québec, Canada

\section{Abstract}

The sulfur cycle is driven by redox processes, among which sulfate reduction is of primary importance. Sulfate is reduced to sulfide either abiotically by Thermochemical Sulfate Reduction (TSR) or biotically by Microbial Sulfate Reduction (MSR). Although these two processes occur at different temperature regimes $\left(>100^{\circ} \mathrm{C}\right.$ and $<80^{\circ} \mathrm{C}$, respectively), they generate similar by-products (e.g., sulfides, elemental sulfur). The ${ }^{34} \mathrm{~S} /{ }^{32} \mathrm{~S}$ ratio is often used as the sole criterion to identify the origin of reduced sulfur compounds, but overlaps prevent unambiguous conclusions. Contrary to MSR, the multiple sulfur isotopic signatures $\left(\delta^{33} \mathrm{~S}, \delta^{34} \mathrm{~S}\right.$, $\delta^{36} \mathrm{~S}$ ) of natural TSR remains uncharacterized. Here, we performed multiple sulfur isotopes 
analyses of sulfates, sulfides, and elemental sulfur from six sites in the Alpine Triassic evaporites formation to better constrain the isotopic signatures of TSR. Unlike MSR, TSR can induce slight negative deviations $\left(\Delta^{33} S\right.$ down to $-0.08 \%$ ) relative to the initial sulfate $\Delta^{33} S$ value, which significantly discriminates between these two processes. Isotopic equilibria between anhydrite and either elemental sulfur or sulfides (pyrite or chalcopyrite) were verified according to their mass-fractionation exponents $\left({ }^{33 / 34} \theta=0.5140\right.$ and 0.5170 , respectively). Using sulfate-elemental sulfur $\left(\Delta^{34} \mathrm{SsO}_{4}{ }^{2-}{ }_{-} \mathrm{S}_{8}\right)$ or sulfate-sulfide $\left(\Delta^{34} \mathrm{SsO}_{4}{ }^{2-}{ }_{-}{ }^{2-}\right)$ fractionation pairs and respective fractionation factors $\left({ }^{34} \alpha\right)$ for samples that fulfilled the criteria of isotopic equilibrium, we determined the precipitation temperatures of elemental sulfur and sulfides (pyrite or chalcopyrite) to be $194 \pm 14{ }^{\circ} \mathrm{C}$ and $293-488{ }^{\circ} \mathrm{C}$, respectively. Interestingly, the obtained temperature of elemental sulfur precipitation corresponds exactly to the solid-liquid phase transition of native sulfur. Using $\Delta^{33} S$ vs. $\delta^{34} S$ and $\Delta^{33} S$ vs. $\Delta^{36} S$ diagrams, we are able to fully explain the isotopic signatures of disequilibrium sulfides by the mixing of sulfate with either elemental or organic sulfur in the aqueous fluid. Mixing curves allow the determination of the relative proportions of sulfate and organic and elemental sulfur, the latter being formed by the recombination of polysulfides during cooling. It appears that the sulfides' signatures are best explained by a 33\% contribution of polysulfides (i.e., elemental sulfur signatures), consistent with the relative proportion of dissolved polysulfides previously measured in fluid inclusions from this formation at $>200{ }^{\circ} \mathrm{C}$. Finally, no sulfur mass independent fractionation (S-MIF) is observed in this evaporitic formation, consistent with the TSR signature generated both at equilibrium and by mixing. This implies that TSR does not generate S-MIFs. Our results thus provide multiple sulfur isotopes signatures of TSR, which may be used to reliably identify this process in variable geological settings.

Keywords: Quadrupole sulfur isotopes, TSR, Sulfur cycle, Isotopic equilibrium, Twocomponents mixing curves, Alps 


\section{INTRODUCTION}

51 Sulfate reduction is one of the most important processes controlling the sulfur cycle; it can occur abiotically (by Thermochemical Sulfate Reduction, TSR), or be driven by biological activity (Microbial Sulfate Reduction, MSR; Machel, 2001). Although MSR generates lesser amounts of the reaction products than TSR, the overall mass balance of the reaction is identical

for the two processes and can be approximated as (here, using methane as a reducing agent):

$$
\mathrm{SO}_{4}{ }^{2-}+\mathrm{CH}_{4} \rightarrow \mathrm{H}_{2} \mathrm{~S}+\mathrm{CO}_{2}+2 \mathrm{OH}^{-}
$$

Apart from methane, the involvement of other reducing agents (e.g., hydrocarbons, $\mathrm{Fe}^{2+}, \mathrm{H}_{2}$ ) leads to different MSR and TSR reactions. In detail, the reaction is much more complex because numerous sulfur species of intermediate valence are involved throughout the transfer of eight electrons from sulfate to sulfide (Goldstein and Aizenshtat, 1994; Farquhar et al., 2007; Johnston et al., 2007; Sim et al., 2011; Truche et al., 2014, 2009; Barré et al., 2017). The two processes can occur sequentially during the diagenetic/tectonic history of a sedimentary basin, or separately accordingly to geological context. Indeed, MSR generally occurs during the early stages of diagenesis at $\mathrm{T}<80^{\circ} \mathrm{C}$ (see review by Machel, 2001). As temperature increases during burial, sulfate-reducing bacteria cease to metabolize (Roussel et al., 2015) and TSR takes over at $\mathrm{T}>100-120{ }^{\circ} \mathrm{C}$ (Machel et al., 1995). The sulfur isotopic compositions $\left(\delta^{34} \mathrm{~S}\right)$ of sulfate and reduced sulfur compounds (elemental sulfur and sulfides) have been used to distinguish TSR from MSR because each process induces specific sulfate-sulfide fractionations $\left(\Delta^{34} \mathrm{SsO}_{4}{ }^{2-}-\mathrm{s}^{2-}=\right.$ $\left.\delta^{34} \mathrm{~S}_{\mathrm{SO}_{4}}{ }^{2-}-\delta^{34} \mathrm{~S}^{2-}\right)$. In the case of MSR, such fractionations range from 15 to $72 \%$; this large range results from the heterogeneous isotopic fractionations associated with distinct sulfatoreducing bacteria that employ different metabolic pathways with various intermediate-valence sulfur species (Machel et al., 1995; Farquhar et al., 2007; Johnston et al., 2007; Sim et al., 2011; Labrado et al., 2019). 
For TSR, the observed isotopic fractionation depends on temperature and it can be kinetically controlled or occur at isotopic equilibrium (e.g., Ohmoto and Lasaga, 1982). Kinetic isotopic fractionations are attributed to the initial rupture of the S-O bond in sulfate, resulting in the relative enrichment of ${ }^{32} \mathrm{~S}$ (depletion of ${ }^{34} \mathrm{~S}$ ) in the reduced product and the depletion of ${ }^{32} \mathrm{~S}$ (enrichment of ${ }^{34} \mathrm{~S}$ ) in the residual sulfate (e.g., Cross, 1999). Experimental studies have shown that kinetic effects lead to a maximum $\Delta^{34} \mathrm{SsO}_{4}{ }^{2-}{ }_{-} \mathrm{S}^{2-}$ value of $12.4 \%$ (e.g., Goldstein and Aizenshtat, 1994; Meshoulam et al., 2016, and references therein). In contrast, at isotopic equilibrium, theoretical calculations using the fractionation factor between $\mathrm{SO}_{4}{ }^{2-}$ and $\mathrm{H}_{2} \mathrm{~S}_{\mathrm{aq}}$ at various temperatures (Eldridge et al., 2016) indicate that $\Delta^{34} \mathrm{SSO}_{4}{ }^{2-}{ }_{-}{ }^{2-}$ ranges from $11 \%$ at 500 ${ }^{\circ} \mathrm{C}$ to $43 \%$ at $100{ }^{\circ} \mathrm{C}$. Because this range overlaps that observed for MSR, $\Delta^{34} \mathrm{SsO}_{4}{ }^{2-}{ }_{-} \mathrm{s}^{2-}$ values alone cannot indisputably discriminate TSR from MSR, whatever the origin of the fractionation (abiotic or biotic, equilibrium or kinetic). At present, additional petrographic and geochemical information is required to reliably identify TSR. Multiple sulfur isotopes analyses $\left(\delta^{33} \mathrm{~S}, \delta^{34} \mathrm{~S}\right.$, $\delta^{36} \mathrm{~S}$ ) have been successfully used to better understand both the isotopic fractionation and the reaction pathways involved during the metabolism of sulfate-reducing bacteria (e.g., Farquhar et al., 2007; Johnston et al., 2007; Zerkle et al., 2009; Sim et al., 2011). However, this technique has not yet been used to characterize the multiple sulfur isotopes signature of the TSR reaction pathway, nor to attempt to discriminate it from that of MSR.

Here, we used multiple sulfur isotopes analysis $\left(\delta^{33} \mathrm{~S}, \delta^{34} \mathrm{~S}, \delta^{36} \mathrm{~S}\right)$ as a promising geochemical tool to characterize the isotopic signature of TSR. This methodology allows both the robust determination of isotopic equilibrium and the calculation of mixing curves between different sulfur reservoirs. Finally, we explore the potential of TSR to generate sulfur mass independent fractionations (S-MIF) signatures. We focus on the "Nappe des Gypses", a meta-evaporitic formation in the western French Alps. Our approach gives access to the temperatures at which 
reduced phases precipitated and allows us to explain the $S$ isotopic signatures of all the S-rich minerals observed.

\section{THE NAPPE DES GYPSES FORMATION}

The studied area encompasses seven evaporite outcrops in the western French Alps near the villages of Modane, Bramans, and Sollières-l'Envers (Arc Valley), the Ambin stream, the Mont-Cenis Lake, the Roubion stream (near Névache village), and Tignes Lake (Fig. 1). The Nappe des Gypses outcrops comprise 100-400 m of massive anhydrite deposits interbedded with dolomitic boudins, micaschists and black shales centimeter to meters in thickness. During the subduction-collision path of the Alps, the Nappe des Gypses formation acted as a major decollement that was crucial to the structuring of the Alps. The formation underwent three metamorphic and deformational events typical of the Alps (namely D1, D2, and D3), which favored fluid-rock interactions (see Barré et al., 2020, for a complete description of the tectonic evolution of the Nappe des Gypses). Sulfides (pyrite and minor chalcopyrite) and elemental sulfur (Fig. 2; Barré et al., 2017) are observed in direct association with anhydrite and recrystallized carbonates (Barré et al., 2020), corresponding to a typical TSR paragenesis (e.g., Machel et al., 1995). In addition, the characteristic intermediate-valence sulfur species required for TSR to occur, $\mathrm{S}_{3}{ }^{-}$and $\mathrm{S}_{n}{ }^{2-}$ (polysulfides), have been identified by in-situ Raman analyses of heated fluid inclusions (Barré et al., 2017). Thus, all physico-chemical conditions necessary for TSR to occur were present in the Nappe des Gypses.

\section{MATERIALS AND METHODS}

\subsection{Multiple sulfur isotopes notation}

We performed multiple sulfur isotopes analyses by measuring $\delta^{33} \mathrm{~S}, \delta^{34} \mathrm{~S}$, and $\delta^{36} \mathrm{~S}$. All results are reported in the conventional $\delta^{\mathrm{x}} S$ notation with respect to Vienna Cañon Diablo Troilite (V-CDT) as:

$$
\delta^{\mathrm{x}} \mathrm{S}=\left({ }^{\mathrm{x}} \mathrm{R}_{\text {sample }} /{ }^{\mathrm{x}} \mathrm{R}_{\text {reference }}-1\right) \times 1000
$$


123 where $x$ is the mass number of the sulfur isotope $(33,34$, or 36$)$ and $R$ is the isotopic ratio ${ }^{x} \mathrm{~S} /{ }^{32} \mathrm{~S}$.

124 The sulfur isotope fractionation factor between two compounds A and B (Hulston and Thode, 125 1965; Ono et al., 2006; Farquhar et al., 2007) is defined as:

$$
{ }^{\mathrm{x}} \alpha_{\mathrm{A}-\mathrm{B}}=\left(\delta^{\mathrm{x}} \mathrm{S}_{\mathrm{A}}+1000\right) /\left(\delta^{\mathrm{x}} S_{\mathrm{B}}+1000\right)
$$
Isotopic fractionation between two minerals, here between the oxidized mineral (sulfate) and its reduced counterparts (sulfide or elemental sulfur), are calculated as:

$$
\Delta^{34} \mathrm{Ss}_{\mathrm{SO}} 4 \approx \delta^{34} \mathrm{~S}_{\text {reduced S }}-\delta^{34} \mathrm{~S}_{\text {sulfate }}
$$

$$
{ }^{x} \lambda_{\mathrm{A}-\mathrm{B}}=\ln \left({ }^{x} \alpha_{\mathrm{A}-\mathrm{B}}\right) / \ln \left({ }^{34} \alpha_{\mathrm{A}-\mathrm{B}}\right),
$$

$$
\text { where } x=33 \text { or } 36 \text {. }
$$

134 reference equilibrium values of 0.515 and 1.90 for ${ }^{33} \lambda$ and ${ }^{36} \lambda$, respectively (Hulston and

135 Thodes, 1965; Ono et al., 2006; Farquhar et al., 2007; Eldridge et al., 2016). For most species, 136 exponent values approaching 0.515 and 1.90 indicate an equilibrium process, whereas kinetic 137 processes deviate from equilibrium values (Ono et al., 2006). These deviations can vary 138 depending on the species present (Farquhar and Wing, 2003) and temperature (Otake et al., 139 2008). Note that, at isotopic equilibrium, ${ }^{33} \lambda_{\text {A-B }}$ and ${ }^{36} \lambda_{\mathrm{A}-\mathrm{B}}$ are conventionally written as ${ }^{33} \theta_{\mathrm{A}-\mathrm{B}}$ 140 and ${ }^{36} \theta_{\mathrm{A}-\mathrm{B}}$, respectively, although the calculation does not differ from that in Eq. (5).

$141 \quad$ We used capital delta values defined as:

$$
\Delta^{33} \mathrm{~S}=\delta^{33} \mathrm{~S}-\left[\left(\delta^{34} \mathrm{~S} / 1000+1\right)^{0.515}-1\right] \times 1000
$$

$143 \quad$ and

$$
\Delta^{36} \mathrm{~S}=\delta^{36} \mathrm{~S}-\left[\left(\delta^{34} \mathrm{~S} / 1000+1\right)^{1.90}-1\right] \times 1000
$$

for a more convenient graphical representation and to facilitate discussion of subtle

146 isotopic variations. Note that ${ }^{36} \mathrm{~S}$ is a minor isotope (abundance $0.02 \%$ ); consequently, the

147 statistical error related to its measurement is greater than those for ${ }^{33} \mathrm{~S}$ and ${ }^{34} \mathrm{~S}$. 
Multiple sulfur isotopic analyses were performed separately on anhydrite, sulfides (pyrite or chalcopyrite), and elemental sulfur samples. Between 2 and 1,000 mg of powder of each mineral phase was collected using a Dremel tool to bore holes 1 or $2 \mathrm{~mm}$ in diameter. This allowed us to precisely target the desired mineral phases within $<1 \mathrm{~mm}$, regardless of the host environment. Sulfur was extracted from each phase by wet chemistry at the Centre de

154 Recherches Pétrographiques et Géochimiques (CRPG, Vandœuvre-Lès-Nancy, France), following previously established species-specific protocols: (i) sulfides were extracted using 5 $\mathrm{N} \mathrm{HCl}$ and a chromium-reduced sulfides (CRS) solution (Canfield et al., 1986); (ii) elemental sulfur was extracted using $5 \mathrm{~N} \mathrm{HCl}$ and a CRS solution with added ethanol to optimize 158 extraction yields (Gröger et al., 2009); and (iii) sulfates were extracted by adding a strongly 159 reducing hydriodic hypophosphorous acid solution (Kitayama et al., 2017). In all cases, $\mathrm{H}_{2} \mathrm{~S}$ 160 was liberated from the rock powder, converted into $\mathrm{Ag}_{2} \mathrm{~S}$ by reaction with an $\mathrm{AgNO}_{3}$ solution, 161 and cleaned with milli-Q water and dissolved ammonia. To determine the efficiency and 162 repeatability of our sulfur extraction procedure, we performed preliminary extractions on pure 163 phases (pyrite, elemental sulfur, anhydrite), which resulted in systematic conversion yields of 164 87-100\%. Such high yields do not impact the measured isotopic compositions (Kitayama et al., 2017). We therefore assume that all our extractions from natural samples (i.e., non-pure phases) resulted in similar extraction yields that did not impact the isotopic compositions. This is

167 confirmed by the good reproducibility of extractions and associated isotopic compositions for 168 replicate analyses of a given same sample.

169 High-precision isotopic measurements by gas-source mass spectrometry require that the sample be analyzed as $\mathrm{SF}_{6}$ to prevent any isobaric interference classically associated with $\mathrm{SO}_{2}$

171 analyses (i.e., due to multiple $\mathrm{O}$ isotopes). The recovered $\mathrm{Ag}_{2} \mathrm{~S}$ was fluorinated in nickel 172 reaction bombs by reaction with excess $\mathrm{F}_{2}$ overnight at $250{ }^{\circ} \mathrm{C}$ to produce $\mathrm{SF} 6$. After purification 
173 using cryogenic traps and gas chromatography, the recovered $\mathrm{SF}_{6}$ was introduced into a

174 ThermoFinnigan MAT 253 dual-inlet gas-source mass spectrometer at the Institut de Physique

175 du Globe de Paris (IPGP, France).

176 Standard deviations on isotopic analyses were estimated as the sum of the internal

177 (corresponding to standard deviation during sample measurement by mass spectrometry) and

178 external errors (corresponding to sulfur extraction and purification steps) after the complete

179 extraction, fluorination, and measurement procedure, and after comparison with International

180 Atomic Energy Agency (IAEA) $\mathrm{Ag}_{2} \mathrm{~S}$ standards S1 and S2. Standard deviations are better than

$181 \quad 0.1 \%, 0.01 \%$, and $0.1 \%$ for $\delta^{34} \mathrm{~S}, \Delta^{33} \mathrm{~S}$, and $\Delta^{36} \mathrm{~S}$, respectively.

182 4. RESULTS

183

\subsection{Petrographic analysis}

Sulfides (mostly pyrite and scarce texturally syngenetic chalcopyrite) are always observed in association with micaschist layers, occurring either as isolated grains/grain clusters in anhydrite facies (Fig. 2A-H-I) or as carbonate-quartz-sulfide veins in micaschists (Fig. 2D).

When micaschists are absent, only elemental sulfur is observed, either well crystallized within fractures in gray dolomite sedimentary layers (often deformed as boudins; Fig. 2B) or in anhydrite deformation structures (Fig. 2C-E-F-G). Sulfides are only observed in centimeter-

190 scale association with elemental sulfur in the presence of micaschist at the Sollières l'Envers 191 outcrop (Fig. 2E).

\section{$192 \quad 4.2 \mathrm{~S}$ isotopic compositions of sulfate, sulfide, and elemental sulfur}

193 We performed multiple sulfur isotopes analyses on 44 samples, comprising three mineral

194 types collected across the six sampling sites: sulfates (anhydrite or gypsum), sulfides (pyrite or 195 chalcopyrite), and elemental sulfur (Table 1). The sulfur isotopic compositions of sulfates and 196 elemental sulfur are rather homogeneous across all six sites (Fig. 3). Anhydrite is enriched in 
198 compared to elemental sulfur $\left(\delta^{34} \mathrm{Ss}_{8}=-18.82\right.$ to $-13.17 \%$, mean $-15.40 \pm 1.91 \%$, and both

199 phases have small non-zero $\Delta^{33} \mathrm{~S}$ and $\Delta^{36} \mathrm{~S}$ values: for anhydrite, $\Delta^{33} \mathrm{~S}_{\text {anhydrite }}=0.00-0.09 \%$ 200 (mean $0.03 \pm 0.03 \%$ ) and $\Delta^{36} \mathrm{~S}_{\text {anhydrite }}=-1.11$ to $+1.26 \%$ (mean $-0.30 \pm 0.69 \%$ ); for elemental 201 sulfur, $\Delta^{33} \mathrm{~S}_{\mathrm{S}_{8}}=0.00-0.06 \%$ (mean $0.02 \pm 0.02 \%$ ) and $\Delta{ }^{36} \mathrm{~S}_{\mathrm{s}_{8}}=-0.95$ to $+1.06 \%$ (mean 0.42 $202 \pm 0.68 \%$ ). Sulfides (without distinction between pyrite and chalcopyrite) display more variable 203 compositions with $\delta^{34} \mathrm{~S}_{\text {sulfide }}=-5.44$ to $+11.60 \%$ (mean $3.14 \pm 4.01 \%$ ) and near-zero values 204 for both $\Delta^{33} \mathrm{~S}\left(0.00 \pm 0.03 \%\right.$ ) and $\Delta^{36} \mathrm{~S}(0.09 \pm 0.54 \%)$. No relationship was observed between 205 sulfur isotopic composition and petrographic context (i.e., native sulfur in fractures or within 206 the schistosity of anhydrite; sulfides disseminated in anhydrite or present in carbonate-quartz207 sulfide veins associated with micaschist layers).

\section{DISCUSSION}

\subsection{Triassic sulfate signatures}

The $\delta^{34} \mathrm{~S}$ values of sulfates from the Nappe des Gypses range from 12.74 to $18.39 \%$, similar to ranges reported in evaporites of the Khuff Formation (Abu Dhabi; Worden et al., 1997) and in gas fields of Alberta (Yang et al., 2001). In both cases, the isotopic compositions were interpreted as being inherited from dissolved sulfate during seawater evaporation. The Upper

214 Triassic age of the Nappe de Gypses evaporites was previously estimated by paleontological 215 studies (Debelmas et al., 1989) and the mean isotopic composition of sulfates reported here $216\left(\delta^{34} \mathrm{~S}=15.44 \pm 1.53 \%\right)$ is consistent with the sulfate signature of Carnian seawater $(16.15 \pm$ 217 1.03\%o) recorded in anhydrite and gypsum from Israel and the Italian Alps (Fig. 3; Claypool et 218 al., 1980; Crockford et al., 2019; and references therein). To our knowledge, the only coupled $219 \delta^{34} S$ and $\Delta^{33} S$ values reported for Carnian seawater are for samples of carbonate associated sulfate (CAS; i.e., traces of seawater sulfate incorporated during carbonate precipitation), with 
with our data $\left(\delta^{34} \mathrm{~S}=15.44 \pm 1.53 \%, \Delta^{33} \mathrm{~S}=0.03 \pm 0.03 \%\right.$ ) $)$ to which we add the first $\Delta^{36} \mathrm{~S}$ values for Carnian seawater: $-0.30 \pm 0.69 \%$.

\subsection{Abiotic formation mechanism of sulfide and elemental sulfur}

Previous studies of natural samples indicate that reduced sulfur minerals (subscript ' $S$ '; i.e., sulfides or elemental sulfur) produced by TSR record isotopic fractionations of no more than $20 \%$ relative to their reactant sulfate (i.e., $\Delta^{34} \mathrm{SsO}_{4-\mathrm{S}} \geq 20 \%$; e.g., Machel et al., 1995; Cross, 1999). Meshoulam et al. (2016, and references therein) experimentally determined that a maximum fractionation of $12.4 \%$ between sulfates and sulfides $\left(\Delta^{34} \mathrm{SSO}_{4}{ }^{2-}{ }_{-}{ }^{2-}\right)$ should be produced by kinetic effects during TSR alone. To our knowledge, only one study has reported a $\Delta^{34} \mathrm{~S}_{\mathrm{SO}_{4}-\mathrm{S}}$ fractionation produced by TSR as high as 35\%o in natural samples (Alonso-Azcárate et al., 2001); they attributed such a high $\Delta^{34} \mathrm{~S}_{\mathrm{SO}_{4}-\mathrm{S}}$ value to limited organic matter availability and high rates of isotopic equilibration. Higher $\Delta^{34} \mathrm{~S}_{\mathrm{SO}_{4}-\mathrm{S}}$ values (up to $75 \%$ ) cannot be explained by abiotic geological processes because of the low inferred temperature and would thus generally result from MSR (e.g., Machel et al., 1995; Labrado et al., 2019).

Our results indicate that $\Delta^{34} \mathrm{~S}_{\mathrm{SO}_{4}}{ }^{2-}{ }_{-} \mathrm{s}^{2-}$ values between anhydrite and associated sulfides range from 4.2 to $20.4 \%$, consistent with TSR. In contrast, $\Delta^{34} \mathrm{~S}_{\mathrm{SO}_{4}}{ }^{2-}{ }_{-} \mathrm{S}_{8}$ values between anhydrite and associated elemental sulfur range from 28.1 to $33.3 \%$; a fractionation of such magnitude is more ambiguous and could potentially record a biological input via MSR. Indeed, the presence of elemental sulfur in salt dome caprocks and other evaporite settings is commonly explained by the late oxidation of $\mathrm{H}_{2} \mathrm{~S}$, which is generated either microbiologically (see review by Labrado et al., 2019) or abiotically (e.g., Machel et al., 1995). The $\delta^{33}$ S value of elemental sulfur can be used to differentiate between the two pathways. Indeed, equilibrium should lead to $\Delta^{33} \mathrm{~S}$ values near zero, whereas previous studies have reported systematic excesses of ${ }^{33} \mathrm{~S}$ in reduced MSR by-products, with $\Delta^{33} \mathrm{~S}$ values up to $0.2 \pm 0.05 \%$ (and associated $\Delta^{34} \mathrm{~S}_{\mathrm{SO}_{4} \text {-S values of } 10-}$ 
75\%o) relative to the initial sulfates (e.g., Farquhar et al., 2007; Zerkle et al., 2009; Johnston,

247 2011; Sim et al., 2011). In the present study, the $\Delta^{33} S$ values of elemental sulfur from all studies 248 sites are $0.00-0.06 \%$, comparable to those of sulfates $(0.00-0.09 \%$; Table 1 , Fig. 4$)$. Such 249 similar values are not consistent with the production of elemental sulfur by a bacterial-mediated reaction mechanism; if that were the case, one would expect the $\Delta^{33} \mathrm{~S}$ values of elemental sulfur to be $0.05-0.2 \%$ greater than those of sulfates. Hence, our data are generally consistent with an equilibrium TSR process. Sulfides show $\Delta^{33} \mathrm{~S}$ values between -0.06 and $+0.06 \%$ (Table 1, Fig. 4), slightly lower than those of sulfates. Moreover, the metamorphic path of the Nappe des (Barré et al., 2020), and the occurrence of elemental sulfur in fractures and deformed anhydrite bedding (Fig. 2B, C, E) implies that it formed during the tectonic evolution of the Nappe des Gypses. Thus, $\mathrm{H}_{2} \mathrm{~S}$ cannot have been generated later by oxidation at the surface, again inconsistent with bacterial activity. This confirms that multiple sulfur isotopes can easily distinguish TSR from MSR, especially based on the $\Delta^{33} \mathrm{~S}$ signatures of the reduced by-products: TSR results in $\Delta^{33} \mathrm{~S}$ values equal or below those of the initial sulfate, whereas MSR leads to 261 higher values.

\subsection{No S-MIF generated during TSR}

Multiple sulfur isotopes analyses are generally used to track photochemical reactions 264 producing sulfur mass independent fractionations (S-MIFs; e.g., Farquhar et al., 2000; 265 Johnston, 2011; Thomassot et al., 2015). Compared with common mass-dependent 266 fractionations that produce zero to near-zero $\Delta^{33} S$ and $\Delta^{36} S$ values, S-MIFs correspond to anomalous $\Delta^{33} \mathrm{~S}$ and $\Delta^{36} \mathrm{~S}$ values that greatly depart from zero. Two studies have reported TSR experiments using concentrated amino acids as a reducing agent to produce significant S-MIFs.

269 Watanabe et al. (2009) showed $\Delta^{33} \mathrm{~S}$ fractionations up to $+2.1 \%$ with associated $\Delta^{36} \mathrm{~S}$ values between -1.1 and $+1.1 \%$ in the amino acid residue; they attributed these fractionations to the 
adsorption of S species on solid mineral surfaces and to a magnetic isotopic effect. Oduro et al.

272 (2011) also attributed the large $\Delta^{33} \mathrm{~S}$ fractionation (up to $+13.1 \%$ ) observed in the residue of

273 their experiments to an ion-radical pair mechanism that would generate a magnetic isotopic

274 effect on odd isotopes (i.e., ${ }^{33} \mathrm{~S}$ ), producing anomalous $\Delta{ }^{33} \mathrm{~S}$ values whereas $\Delta^{36} \mathrm{~S}$ remains mass-

275 dependent. They also concluded that TSR is not directly responsible for such fractionations

276 because, so far, no study on natural samples has revealed a S-MIF specifically of odd isotopes.

277 Several studies have also speculated that the involvement of the radical ion $\mathrm{S}_{3}{ }^{-}$in the $\mathrm{TSR}$

278 process may contribute to anomalous sulfur isotopic compositions (Truche et al., 2014;

279 Pokrovski and Dubessy, 2015; Barré et al., 2017) due to its interesting symmetry properties that

280 are comparable to those of ozone which induces mass-independent oxygen isotopic

281 fractionations (Michalski and Bhattacharya, 2009). However, recent experiments producing

282 radical sulfur ions did not show any significant anomalies under the investigated conditions

283 (Kokh et al., 2020), although their experiments did not directly correspond to TSR because their experimental setup did not involve a reducing agent. These experimental studies demonstrate that the different mechanisms associated with TSR process may or may not generate S-MIFs.

286 Nonetheless, none of these experiments are representative of natural TSR conditions. It is 287 therefore essential to identify the signature of TSR under natural conditions.

288 Only one study has documented S-MIF in natural sulfide samples for which TSR is suspected, showing $\Delta^{33} \mathrm{~S}$ values up to $+1.25 \%$ in Paleoproterozoic shales (Young et al., 2013).

290 However, $\mathrm{Hu}$ et al. (2020) showed that the reduction of sulfates with initial non-zero $\Delta^{33} \mathrm{~S}$ 291 values will produce sulfides along a classical mass-dependent line, which will thus preserve the 292 initial anomalous signature of the sulfates. Thus, the S-MIF observed by Young et al. (2013) in 293 Paleoproterozoic black shales may result from the reduction of sulfates or the leaching of 294 Archean sulfides that already exhibited non-zero $\Delta^{33} \mathrm{~S}$ values. Therefore, without direct 
evidence of the occurrence of TSR in those rocks, it is impossible to prove that the observed S-

296 MIF truly results from TSR.

297 In our study of the Nappe des Gypses formation, despite the clear occurrence of TSR and the 298 presence of dissolved $\mathrm{S}_{3}{ }^{-}$as well as polysulfides $\left(\mathrm{S}_{n}{ }^{2-}\right)$ in fluid inclusions heated above $200{ }^{\circ} \mathrm{C}$ 299 (Barré et al., 2017), we do not observe any significant S-MIF: $\Delta^{33} S_{\text {anhydrite }}=0.03 \pm 0.03 \%$, $\Delta^{33} \mathrm{~S}_{\text {sulfide }}=0.00 \pm 0.03 \%$, and $\Delta^{33} \mathrm{~S}_{8}=0.02 \pm 0.02 \%$, and $\Delta^{36} \mathrm{~S}_{\text {anhydrite }}=-0.30 \pm 0.69 \%$, $\Delta^{36} \mathrm{~S}_{\text {sulfide }}=0.09 \pm 0.54 \%$, and $\Delta{ }^{36} \mathrm{~S}_{\mathrm{S}_{8}}=0.42 \pm 0.68 \%$ (Table 2). In conclusion, our results do not evidence any TSR-driven mass-independent fractionation.

\subsection{Equilibrium vs. disequilibrium as reflected by isotopic composition}

The use of isotopic geothermometers based on the fractionation factor between two syngenetic chemical species requires that they be in isotopic equilibrium. In most cases, this requirement is inferred based on petrographic observations. When two mineral species appear

to be syngenetic, it is considered that they are at isotopic equilibrium. Jamieson et al. (2006) used multiple sulfur isotopes analyses to investigate the isotopic equilibrium between sulfide pairs (i.e., two sulfide species considered to be syngenetic) based on their respective $\delta^{34} \mathrm{~S}$ and $\Delta^{33} \mathrm{~S}$ values. They showed that, given geological context and depending on the phases involved, two minerals with different $\delta^{34} \mathrm{~S}$ values but similar $\Delta^{33} \mathrm{~S}$ values are considered to be at isotopic 312 equilibrium. By following a similar approach in our case study, it is possible to demonstrate if 313 the reduced sulfur minerals and sulfates are truly at isotopic equilibrium.

314 Here, we used ${ }^{34} \mathrm{~S} /{ }^{32} \mathrm{~S}$ fractionation factors at relevant temperatures between aqueous sulfates 315 and aqueous $\mathrm{H}_{2} \mathrm{~S}$ from Eldridge et al. (2016) and between aqueous sulfates and aqueous 316 elemental sulfur $\left(\mathrm{S}_{8}\right)$ from Eldridge et al. (2021) to determine the equilibrium temperatures of 317 the different reduced sulfur compounds (Table 2). Using this method, the apparent precipitation 318 temperatures of some sulfides are higher (up to $980{ }^{\circ} \mathrm{C}$; Table 2) than the metamorphic peak temperature of the Nappe des Gypses formation $\left(431 \pm 28{ }^{\circ} \mathrm{C}\right.$; Barré et al., 2020) despite 
petrographic criteria indicating the phases to be syngenetic (Fig. 2). This implies that

321 petrographic observations are not always a robust diagnostic tool for evaluating isotopic equilibrium.

Fortunately, the relationships between the ${ }^{33 / 32} \mathrm{~S},{ }^{34 / 32} \mathrm{~S}$ and ${ }^{36 / 32} \mathrm{~S}$ fractionations (i.e., the mass fractionation exponents $\lambda$ ) can be used as an independent test of whether two species are in isotopic equilibrium. We determined the mass-fractionation exponents ${ }^{33} \lambda$ and ${ }^{36} \lambda$ (corresponding to the slopes of mass-dependent signatures in the $\delta^{33} \mathrm{~S}$ vs. $\delta^{34} \mathrm{~S}$ and $\delta^{36} \mathrm{~S}$ vs. $\delta^{34} \mathrm{~S}$ diagrams, respectively) between sulfates and the associated reduced forms (elemental sulfur or sulfides) observed at each studied site (Table 2). We then further compared these massfractionation exponents, associated with their previously determined equilibrium temperatures, to those derived from theoretical calculations (Otake et al., 2008; Eldridge et al., 2016; Eldridge et al., 2021). Considering the different sulfur species observed $\left(\mathrm{H}_{2} \mathrm{~S}_{\mathrm{aq}}, \mathrm{SO}_{3}{ }^{2-}, \mathrm{S}_{8}, \mathrm{~S}_{3}{ }^{-}, \mathrm{S}_{n}{ }^{2-}\right.$ and $\mathrm{CS}_{2 \mathrm{aq}}$ ), theoretical calculations give ${ }^{33} \theta$ values (i.e., ${ }^{33} \lambda$ at isotopic equilibrium) between 0.5143 and 0.5158 and ${ }^{36} \theta$ values (i.e., ${ }^{36} \lambda$ at isotopic equilibrium) between 1.8783 and 1.9223 for temperatures of $25-1000{ }^{\circ} \mathrm{C}$ (Fig. 5). We note that, when plotting $\delta^{33} \mathrm{~S}$ vs. $\delta^{34} \mathrm{~S}$ and $\delta^{36} \mathrm{~S}$ vs. $\delta^{34} \mathrm{~S}$, larger $\Delta^{34} \mathrm{~S}$ values (i.e., lower temperatures), provide more precise values of ${ }^{33} \lambda$ and ${ }^{36} \lambda$; this is why the errors on $\lambda$ values are larger at higher temperatures than at lower temperatures. For that reason, $\lambda$ values associated with high uncertainties cannot be used to demonstrate or infer isotopic equilibrium. This implies that the determination of the mass fractionation exponents mainly depends on the analytical precision and associated error on $\delta^{33} \mathrm{~S}, \delta^{34} \mathrm{~S}$ and $\delta^{36} \mathrm{~S}$. Here, we use only the ${ }^{33} \lambda$ values to determine if a mineral pair is consistent with isotopic equilibrium because the precision on ${ }^{36} \mathrm{~S}$ measurements is lower than that for ${ }^{33} \mathrm{~S}$; the ${ }^{36} \lambda$ values presented in Table 2 are included only to broaden the published dataset. We consider a mineral pair to be at isotopic equilibrium only if the associated ${ }^{33} \lambda$ value is between 0.5140 and 0.5170 ; only in that case do we consider the associated equilibrium temperature (Fig. 5). 
346 and elemental sulfur $\left({ }^{33} \lambda_{\mathrm{SO}_{4}-\mathrm{S}_{8}}\right)$ at all analyzed sites are between 0.51467 and 0.51632 (Table 2,

347 Fig. 5), implying that sulfates and all elemental sulfur samples are consistent with isotopic 348 equilibrium. Their corresponding equilibrium temperatures are in the range $172-217{ }^{\circ} \mathrm{C}$ (Table

349 2, Fig. 5). These temperatures correspond to the liquid-solid phase transition of elemental sulfur at the lowest P-T conditions recorded by the Nappe des Gypses formation (Fig. 6; Barré et al., 2020). This result implies with a unique P-T condition at which all elemental sulfur throughout the formation precipitated at the same time, which accounts for the similar isotopic signatures of all the analyzed samples. Interestingly, fluid inclusions from this evaporitic formation contain tiny crystals of elemental sulfur, in addition to sulfates and sulfides that are dissolved in the brines at room temperature. This elemental sulfur disproportionates when heating the fluid inclusions to $>200{ }^{\circ} \mathrm{C}$ and significant concentrations (milli-molar range) of polysulfides (including the $\mathrm{S}_{3}{ }^{-}$radical ion) were measured by in-situ Raman spectroscopy (Barré et al., 2017). This indicates that elemental sulfur precipitates directly from the recombination of dissolved polysulfides (Steudel and Chivers, 2019) involved in TSR (Barré et al., 2017). Consequently, the elemental sulfur, as collected herein from the Nappe des Gypses formation, records the TSR-driven isotopic signatures of the polysulfides from which it formed. between sulfates and sulfides $\left({ }^{33} \lambda_{\mathrm{SO}_{4}-\mathrm{H}_{2} \mathrm{~S}}\right)$, only three of eleven samples are consistent with equilibrium isotopic exchange reactions: two pyrites from the Sollières and Ambin outcrops and one chalcopyrite from the Mont-Cenis Lake outcrop (Fig. 4C-E). Their equilibrium temperatures are $293 \pm 20{ }^{\circ} \mathrm{C}, 344 \pm 20{ }^{\circ} \mathrm{C}$, and $488 \pm 55^{\circ} \mathrm{C}$, respectively (Table 2, Fig. 5), 367 consistent with the kinetics of the isotopic equilibrium between $\mathrm{SO}_{4}{ }^{2-}$ and $\mathrm{H}_{2} \mathrm{~S}$, which is 368 attained within a few days at $>350^{\circ} \mathrm{C}$ (Ohmoto and Lasaga, 1982). These temperatures match well with the D2-D3 transition phase $\left(259 \pm 24^{\circ} \mathrm{C}\right)$, the D1-D2 transition $\left(350 \pm 20^{\circ} \mathrm{C}\right)$, and 
the peak metamorphic temperature $\left(431 \pm 28{ }^{\circ} \mathrm{C}\right)$ of the Nappe des Gypses formation, respectively (Barré et al., 2020). This result suggests that TSR occurred at least from the metamorphic peak to the D2-D3 transition phase during the exhumation of the host formation.

All other samples present ${ }^{33} \lambda_{\mathrm{SO}_{4}-\mathrm{H}_{2} \mathrm{~S}}$ values between 0.517 and 0.523 , i.e., significantly

deviating from the estimated isotopic equilibrium range (Fig. 5). They cannot be at isotopic equilibrium, and therefore their derived "equilibrium temperatures" are not considered further. This means that another process was involved in their precipitation, as discussed in the following subsection.

\subsection{Evidence of mixing between sulfates and elemental sulfur}

In this subsection, we focus on the eight sulfide samples with ${ }^{33} \lambda \mathrm{SO}_{4}-\mathrm{H}_{2} \mathrm{~S}$ values of $0.517-$ 0.523 that deviate significantly from the theoretical equilibrium value of 0.515 (Table 2, Fig. 5). Such deviations could reflect kinetically controlled $S$ fractionation during sulfide precipitation. However, kinetic mechanisms generally involve percent-level deviations towards values below that of isotopic equilibrium (Ono et al., 2006); for oxygen isotopes, for example, the $\lambda$ value can be lowered from the equilibrium value by 0.027 in an abiotic reaction (Clayton and Mayeda, 2009). Here, the ${ }^{33} \lambda$ values deviate from the previously determined isotopic equilibrium range $(0.5148-0.5163)$ by +0.0021 to +0.0080 . Because these values are higher than those at equilibrium, it is unlikely that they result from simple, unidirectional mechanisms. Alternatively, mixing between two reservoirs might explain such observations. To test this hypothesis, we performed two-component mixing calculations on $\delta^{34} \mathrm{~S}, \Delta^{33} \mathrm{~S}$, and $\Delta^{36} \mathrm{~S}$. In our calculation, mixing between two pools occurs in the aqueous phase and the resulting isotopic composition derives from the proportion of each species in the fluid. Because TSR occurs in solution, mixing is possible between any two of the various sulfur species involved in the reaction (i.e., sulfates, sulfides, elemental sulfur, polysulfides, organic sulfur species, and other 
minor intermediate-valence species; Goldstein and Aizenshtat, 1994; Meshoulam et al., 2016;

395 Barré et al., 2017).

396 The sulfur reservoirs considered here are (1) dissolved Triassic sulfates, (2) elemental sulfur

397 (corresponding to polysulfides dissolved in the hot fluid formed at isotopic equilibrium; see

398 section 5.4), and (3) dissolved organic sulfur. Regarding the latter, evaporites of Upper Triassic

399 (Carnian) age are known to present sedimentation conditions with high potential for sulfur-rich

400 kerogen deposition (Cota and Baric, 1998). During the burial and exhumation history of the

401 formation, these sulfur-rich kerogens can experience thermal cracking, releasing organic sulfur

402 species into the fluid. Here, stromatolitic dolomites and black shales are observed in the Nappe 403 des Gypses formation (Barré et al., 2020), which are good candidates for sedimentary facies 404 containing S-rich kerogen. However, the kerogen in these rocks is too thermally mature to 405 expect any preservation of organic sulfur, precluding the direct determination of its isotopic composition. Therefore, we used a theoretical organic S reservoir with a $\delta^{34} \mathrm{~S}$ signature of $-30 \%$, consistent with values reported for the organic sources of $\mathrm{H}_{2} \mathrm{~S}$ in several sour gas fields (Werne et al., 2004, and references therein). We note that, because anhydrite is present in large excess compared to the other sulfur species, we consider sulfates as an infinite reservoir. The 410 sulfate isotopic signature therefore remains constant throughout our calculation of the 411 geological history of the Nappe des Gypses.

412 Mixing curves between sulfates and elemental sulfur (or organic sulfur) are calculated as:

$$
\left(\frac{\delta^{x} S_{m i x}}{1000}+1\right)=\left(\frac{\delta^{x} S_{\mathrm{S}_{8}}}{1000}+1\right) \times \chi_{\mathrm{S}_{8}}+\left(\frac{\delta^{x} S_{\mathrm{SO}_{4}}}{1000}+1\right) \times \chi_{\mathrm{SO}_{4}}
$$

414 where $x=33,34$, or $36, \chi \mathrm{s}_{8}$ and $\chi \mathrm{SO}_{4}$ are the proportions (between 0 and 1) of elemental sulfur 415 ( $\mathrm{S}_{8}$; or organic sulfur) and sulfate $\left(\mathrm{SO}_{4}\right)$, respectively, and $\delta^{x} \mathrm{~S}_{\text {mix }}$ is the isotopic value obtained 416 by mixing of the measured sulfate and elemental sulfur compositions. The associated $\Delta^{33} \mathrm{~S}$ and $417 \Delta^{36} \mathrm{~S}$ values are then deduced from $\delta^{x} S_{\text {mix }}$ using Eqs. (6) and (7). We note that in the $\Delta^{33} S$ vs. $418 \delta^{34} \mathrm{~S}$ and $\Delta^{36} \mathrm{~S}$ vs. $\Delta^{33} \mathrm{~S}$ diagrams (Figs. 4 and 7, respectively), a mixture between two reservoirs 
corresponds to a curve, instead of a line as in a $\delta$ vs. $\delta$ diagram. For mixing to be a viable hypothesis, both the $\Delta^{33} \mathrm{~S}$ and $\Delta^{36} \mathrm{~S}$ values of the sulfides must be satisfactorily explained. equal or lower than those of associated sulfate and elemental sulfur, and $\delta^{34} \mathrm{~S}$ values between +11.60 and $-0.30 \%$. The obtained mixing curves are illustrated in the $\Delta^{33} \mathrm{~S}$ vs. $\delta^{34} \mathrm{~S}$ and $\Delta^{33} \mathrm{~S}$ vs. $\Delta^{36}$ S diagrams (Figs. 4 and 7, respectively), showing that most of the sulfides (five of eight samples) are consistent with mixing between sulfate and elemental sulfur (representing dissolved polysulfides) to produce $\mathrm{H}_{2} \mathrm{~S}$, the latter two species being generated during TSR. The mixing curves allow us to determine the relative proportions of each isotopic reservoir recorded by a single sulfide. Here, the proportion of elemental sulfur (i.e., dissolved polysulfides at higher temperature) ranges between 18 and 50\% (mean $33 \pm 10 \%$ ), in good agreement with the proportion of dissolved polysulfides measured in fluid inclusions from the Nappe des Gypses formation, which can represent up to $25 \%$ of the total dissolved sulfur concentration in the fluid at $300{ }^{\circ} \mathrm{C}$ (Barré et al., 2017), and probably more at higher temperature (Pokrovski and Dubessy, 2015). Given a mixture of $33 \%$ elemental sulfur $\left(\delta^{34} \mathrm{~S}=-15.40 \pm 1.91 \%\right.$, $\Delta^{33} \mathrm{~S}=$ $0.016 \pm 0.018 \%$ o, $\Delta^{36} \mathrm{~S}=0.421 \pm 0.680 \%$ ) with $67 \%$ sulfate $\left(\delta^{34} \mathrm{~S}=15.44 \pm 1.53 \%\right.$ o, $\Delta^{33} \mathrm{~S}=$ $0.033 \pm 0.027 \%$ o, $\Delta^{36} \mathrm{~S}=-0.297 \pm 0.690 \%$ ) , our calculation predicts the resulting sulfide isotopic composition to be $\delta^{34} \mathrm{~S}=-2.33 \pm 2.35 \%, \Delta^{33} \mathrm{~S}=-0.0030 \pm 0.0011 \%$, and $\Delta^{36} \mathrm{~S}=$ $0.1826 \pm 0.0685 \%$. These values are very similar to the mean values measured in the observed sulfides $\left(\delta^{34} \mathrm{~S}=3.14 \pm 4.01 \%, \Delta^{33} \mathrm{~S}=-0.0025 \pm 0.0316 \%\right.$, $\Delta^{36} \mathrm{~S}=0.0873 \pm 0.5423 \%$; Fig. 8$)$. This result is consistent with previous reports that isotopic exchanges between polysulfides and $440 \mathrm{H}_{2} \mathrm{~S}$ are extremely fast, even at room temperature, and that solid sulfides record up to $31 \%$ of 441 the isotopic signature of the polysulfides from which they formed (Fossing and Jørgensen, 442 1990; Fossing et al., 1992). Therefore, we conclude that the isotopic compositions of the observed sulfides represent the mixture of $\sim 67 \%$ sulfate signature with $\sim 33 \%$ elemental sulfur 
signature (i.e., dissolved polysulfides at temperature) at conditions corresponding to isotopic

445

446 equilibrium.

Mixing between sulfate and organic sulfur. At Névache and Bramans, three sulfides present $\Delta^{33} \mathrm{~S}$ values slightly lower than those at the other localities (Fig. 4A, B) but consistent with mixing between sulfate and elemental sulfur, considering the $1 \sigma$ error. However, taken together, their $\Delta^{33} \mathrm{~S}$ and $\Delta^{36} \mathrm{~S}$ values are not consistent with mixing between sulfates and elemental sulfur (Fig. 7A, B), implicating another sulfur reservoir. For these three samples, we assumed mixing between sulfate and a theoretical organic sulfur reservoir (again with $\delta^{34} \mathrm{~S}=-30 \%$, see above). We estimated the $\Delta^{33} \mathrm{~S}$ and $\Delta{ }^{36} \mathrm{~S}$ values of organic sulfur (using ${ }^{33} \lambda=0.5152$ and ${ }^{36} \lambda=1.89$ ) that reproduce the three samples in both the $\Delta^{33} \mathrm{~S}$ vs. $\delta^{34} \mathrm{~S}$ and $\Delta^{33} \mathrm{~S}$ vs. $\Delta^{36} \mathrm{~S}$ diagrams. We obtained relative mixing proportions of organic sulfur of $28 \%$ at Névache and $22 \%$ at Bramans.

The good correlation between the mixing curves in both the $\Delta^{33} \mathrm{~S}$ vs. $\delta^{34} \mathrm{~S}$ and $\Delta^{33} \mathrm{~S}$ vs. $\Delta^{36} \mathrm{~S}$ diagrams is consistent with the sulfur sources belonging to the Nappe des Gypses formation, and no other process than TSR is required. Because the observed compositions do not require an exogenous sulfur-rich fluid, the sulfides must have formed in a closed system. As mixing occurs in the aqueous phase, this implies that all sulfides precipitated before elemental sulfur crystallized, and that TSR probably ceased after the D2-D3 transition during cooling (corresponding to a change in tectonic regime that lead the last exhumation step of the Nappe des Gypses formation; Barré et al., 2020).

\subsection{Implications for the TSR mechanism}

Our multiple sulfur isotopes results complement studies on MSR (e.g., Farquhar et al., 2007; Johnston et al., 2007; Zerkle et al., 2009; Sim et al., 2011) and show that TSR and MSR can be unambiguously discriminated based on the near zero to slightly negative (TSR) and positive (MSR) $\Delta^{33} \mathrm{~S}$ values of all participating reduced sulfur-bearing phases. This geochemical tool can therefore prove extremely useful for better deciphering the sulfur cycle in contexts where 
the occurrence of the two processes is debated (e.g., petroleum systems, ore deposits, hydrothermal settings).

471 These results also provide a new understanding of the TSR reaction pathway and associated 472 isotopic exchanges. The fluids of the Nappe des Gypses formation are considered to have been 473 in a closed system because they mainly correspond to gypsum dehydration and connate 474 seawater without the involvement of external fluid (Grappin et al., 1979). This implies that TSR 475 products in a closed system may or may not be at isotopic equilibrium with a single fluid under similar conditions, which can be explained by the variable availability of dissolved metals. Here, iron was released at different stages of the Nappe des Gypses metamorphic path (Barré et al., 2020), implying a variable metal concentration in the fluid through time. When the metal concentration is sufficiently high, all the $\mathrm{H}_{2} \mathrm{~S}$ precipitates and no intermediate-valence sulfur species (i.e., polysulfides, $\mathrm{S}_{3}{ }^{-}$) remain in the fluid because they are only stable when both sulfates and sulfides are in solution (Truche et al., 2014; Pokrovski and Dubessy, 2015; Barré et al., 2017). In this case, the fractionation between sulfate and precipitating sulfide is temperature dependent and occurs at isotopic equilibrium. In contrast, if $\mathrm{H}_{2} \mathrm{~S}$ is in excess with respect to dissolved metals, only some $\mathrm{H}_{2} \mathrm{~S}$ would precipitate. The resulting sulfide mineral would thus have an isotopic composition corresponding to mixing between the dissolved sulfur species (sulfates and polysulfides; Fig. 8), facilitated by the rapid isotopic exchange between polysulfides and $\mathrm{H}_{2} \mathrm{~S}$ (Fossing and Jørgensen, 1990). The variable availability of metal in the system thus offers a plausible explanation for the distinct isotopic compositions of sulfides from 489 the same geological context and involving only one fluid during TSR.

\section{CONCLUSIONS}

We presented a multiple sulfur isotopes analysis of coexisting sulfates, elemental sulfur, and

492 sulfides in the Nappe des Gypses formation to characterize the reaction pathway of TSR and 493 distinguish TSR from MSR. Our main conclusions are: 
1. Multiple sulfur isotopes analysis can unambiguously differentiate TSR from MSR. Whereas MSR produces sulfide by-products with $\Delta^{33} S$ values above those of reacted sulfates, TSR produces sulfides with similar or lower $\Delta^{33} \mathrm{~S}$ values (down to $-0.08 \%$ ).

2. We used mass-fractionation exponents $\left({ }^{33} \lambda\right.$ and $\left.{ }^{36} \lambda\right)$ to determine if S-bearing mineral pairs (sulfate-elemental sulfur or sulfate-sulfide) were at isotopic equilibrium. We demonstrate that this technique is far more robust than petrographic observations of syngenetic relationships to resolve this crucial point for isotopic geothermometry. We also determined and validated the precipitation temperatures of TSR by-products (i.e., pyrite, chalcopyrite, or elemental sulfur) based on the ${ }^{34} \mathrm{~S}$ fractionation factors between aqueous sulfates and reduced $\mathrm{S}$ species (sulfides or polysulfides). Interestingly, elemental sulfur precipitated between 172 and $217^{\circ} \mathrm{C}$, temperatures that correspond to the elemental sulfur liquid-solid phase transition at the lowest $P-T$ conditions recorded in the Nappe des Gypses formation.

3. Multiple sulfur isotopes analysis also allows interpretation of the isotopic compositions of all sulfides that are not at isotopic equilibrium. Whereas kinetic effects cannot explain these signatures, the two-component mixing calculations show that sulfides precipitated from a mixture between either sulfates and elemental sulfur (i.e., polysulfides at $>200^{\circ} \mathrm{C}$ ) or sulfates and organic sulfur. The obtained mixing curves show that the sulfide compositions are best reproduced by the mixing of $67 \%$ sulfates and $33 \%$ elemental sulfur, consistent with the proportion of dissolved polysulfides measured at $>200{ }^{\circ} \mathrm{C}$ in fluid inclusions from the Nappe des Gypses formation (Barré et al., 2017).

4. We observed no evidence of S-MIF, even though we demonstrated the occurrence of TSR and investigated three S-bearing phases (sulfate, sulfide, and elemental sulfur) at isotopic equilibrium. 
This study opens new perspectives for improving our understanding of the sulfur cycle, especially TSR-related hydrothermal-metamorphic ores or sour gas fields. The multiple sulfur isotopic approach can be used to discriminate MSR from TSR; its systematic application and careful interpretation of the obtained results will improve our understanding of both the isotopic fractionations and the reaction pathways involved in TSR.

\section{Acknowledgements}

This work was funded by LABEX ANR-10-LABX-21-01 Ressources21 (Strategic metal resources of the 21st Century), the French Ministry of Higher Education and Research, and the project Dear_Sir (ANR-15-CE31-0005). The authors would like to thank Robert Dennen who improved the fluidity and grammar of the paper. The paper was greatly improved thanks to relevant and detailed reviews by Simon Bottrell, two anonymous reviewers, and editorial support by Timothy Lyons.

\section{References}

531 Alonso-Azcárate, J., Bottrell, S.H., Tritlla, J., 2001. Sulfur redox reactions and formation of native sulfur veins during low grade metamorphism of gypsum evaporites, Cameros Basin (NE Spain). Chem. Geol. 174(4), 389-402.

Barré, G., Strzerzynski, P., Michels, R., Guillot, S., Cartigny, P., Thomassot, E., Lorgeoux, C., Assayag, N., Truche, L., 2020. Tectono-metamorphic evolution of an evaporitic décollement as recorded by mineral and fluid geochemistry: The "Nappe des Gypses" (Western Alps) case study. Lithos, 358, 105419.

Barré, G., Truche, L., Bazarkina, E.F., Michels, R., Dubessy, J., 2017. First evidence of the trisulfur radical ion $\mathrm{S}_{3}{ }^{-}$and other sulfur polymers in natural fluid inclusions. Chem. Geol. $462,1-14$ 
541 Canfield, D.E., Raiswell, R., Westrich, J.T., Reaves, C.M., Berner, R.A., 1986. The use of chromium reduction in the analysis of reduced inorganic sulfur in sediments and shales. Chem. Geol. 54(1-2), 149-155.

544 Claypool, G.E., Holser, W.T., Kaplan, I.R., Sakai, H., Zak, I., 1980. The age curves of sulfur and oxygen isotopes in marine sulfate and their mutual interpretation. Chem. Geol. 28, 199260.

Clayton, R.N., Mayeda, T.K., 2009. Kinetic isotope effects in oxygen in the laboratory dehydration of magnesian minerals. J. Phys. Chem. A, 113(10), 2212-2217.

Cota, L., Baric, G., 1998. Petroleum potential of the Adriatic offshore, Croatia. Org. Geochem. 29(1-3), 559-570.

Crapanzano, L. (2005). Polymorphism of sulfur: structural and dynamical aspects (Doctoral dissertation, Université Joseph-Fourier-Grenoble I).

Crockford, P.W., Kunzmann, M., Bekker, A., Hayles, J., Bao, H., Halverson, G.P., Peng, Y., Claypool continued: Extending the isotopic record of sedimentary sulfate. Chem. Geol.,

Debelmas, J., Desmons, J., Ellenberger, F., Goffé, B., Fabre, J., Jaillard, E., and Pachoud, A., 1989. Notice explicative de la feuille Modane. B.R.G.M., scale 1/50 000, 1 sheet, 53 p. text $513,200-225$.

Cross, M.M., 1999. Rates and mechanisms of thermochemical sulphate reduction (Doctoral dissertation, Manchester University). (in french).

Eldridge, D.L., Guo, W., Farquhar, J., 2016. Theoretical estimates of equilibrium sulfur isotope sulfoxylate systems. Geochim. Cosmochim. Acta 195, 171-200. 
Eldridge, D.L., Kamyshny Jr, A., Farquhar, J., 2021. Theoretical estimates of equilibrium sulfur isotope effects among aqueous polysulfur and associated compounds with applications to authigenic pyrite formation and hydrothermal disproportionation reactions. Geochim. Cosmochim. Acta 310, 281-319.

Farquhar, J., Bao, H., Thiemens, M., 2000. Atmospheric influence of Earth's earliest sulfur cycle. Science 289(5480), 756-758.

Farquhar, J., Johnston, D.T., Wing, B.A., 2007. Implications of conservation of mass effects on mass-dependent isotope fractionations: influence of network structure on sulfur isotope phase space of dissimilatory sulfate reduction. Geochim. Cosmochim. Acta 71(24), 58625875 .

Farquhar, J., Wing, B.A., 2003. Multiple sulfur isotopes and the evolution of the atmosphere. Earth Planet. Sci. Lett. 213(1), 1-13.

Fossing, H., Jørgensen, B.B., 1990. Isotope exchange reactions with radiolabeled sulfur compounds in anoxic seawater. Biogeochemistry 9(3), 223-245.

Fossing, H., Thode-Andersen, S., Jørgensen, B.B., 1992. Sulfur isotope exchange between 35Slabeled inorganic sulfur compounds in anoxic marine sediments. Marine Chemistry 38(12), 117-132.

Goldstein, T.P., Aizenshtat, Z., 1994. Thermochemical sulfate reduction: A review. J. Therm. Anal. 42, 241-290.

Grappin, C., Saliot, P., Sabouraud, C., Touray, J.C., 1979. Les variations des rapports Cl/Br, $\mathrm{Na} / \mathrm{Br}$ et $\mathrm{K} / \mathrm{Br}$ dans les inclusions fluides des quartz de la cicatrice évaporitique de Bramans-Termignon (Vanoise, Alpes françaises). Chem. Geol. 25(1-2), 41-52.

Gröger, J., Franke, J., Hamer, K., Schulz, H.D., 2009. Quantitative recovery of elemental sulfur and improved selectivity in a chromium-reducible sulfur distillation. Geostand. Geoanal. Res. 33(1), 17-27. 
Hu, D., Li, M., Zhang, X., Turchyn, A.V., Gong, Y., Shen, Y., 2020. Large mass-independent sulphur isotope anomalies link stratospheric volcanism to the Late Ordovician mass extinction. Nature communications, 11(1), 1-8.

Hulston, J.R., Thode, H.G., 1965. Variations in the S33, S34, and S36 contents of meteorites and their relation to chemical and nuclear effects. J. Geophys. Res. 70(14), 3475-3484.

Jamieson, J.W., Wing, B.A., Hannington, M.D., Farquhar, J., 2006. Evaluating isotopic equilibrium among sulfide mineral pairs in Archean ore deposits: case study from the Kidd Creek VMS deposit, Ontario, Canada. Econ. Geol. 101(5), 1055-1061.

Johnston, D.T., 2011. Multiple sulfur isotopes and the evolution of Earth's surface sulfur cycle. Earth-Sci. Rev. 106(1), 161-183.

Johnston, D.T., Farquhar, J., Canfield, D.E., 2007. Sulfur isotope insights into microbial sulfate reduction: when microbes meet models. Geochim. Cosmochim. Acta 71(16), 3929-3947.

Kitayama, Y., Thomassot, E., Galy, A., Golovin, A., Korsakov, A., d'Eyrames, E., Assayag, N., Bouden, N. Ionov, D., 2017. Co-magmatic sulfides and sulfates in the Udachnaya-East pipe (Siberia): A record of the redox state and isotopic composition of sulfur in kimberlites and their mantle sources. Chem. Geol. 455, 315-330.

Kokh, M.A., Assayag, N., Mounic, S., Cartigny, P., Gurenko, A., Pokrovski, G.S., 2020. Multiple sulfur isotope fractionation in hydrothermal systems in the presence of radical ions and molecular sulfur. Geochim. Cosmochim. Acta 285, 100-128.

Labrado, A.L., Brunner, B., Bernasconi, S.M., Peckmann, J., 2019. Formation of large native sulfur deposits does not require molecular oxygen. Front. Microbiol. 10, 24.

Machel, H.G., 2001. Bacterial and thermochemical sulfate reduction in diagenetic settings old and new insights. Sediment. Geol. 140, 143-175.

Machel, H.G., Krouse, H.R., Sassen, R., 1995. Products and distinguishing criteria of bacterial and thermochemical sulfate reduction. Appl. Geochem. 10(4), 373-389. 
616 Meshoulam, A., Ellis, G.S., Ahmad, W.S., Deev, A., Sessions, A.L., Tang, Y., Adkins, J.F., 617 Jinzhong, L., Gilhooly, W.P., Aizenshtat, Z., Amrani, A., 2016. Study of thermochemical 618 sulfate reduction mechanism using compound specific sulfur isotope analysis. Geochim. 619 Cosmochim. Acta 188, 73-92.

620 Michalski, G., Bhattacharya, S.K., 2009. The role of symmetry in the mass independent isotope effect in ozone. Proc. Natl. Acad. Sci. U.S.A. 106(14), 5493-5496.

Oduro, H., Harms, B., Sintim, H.O., Kaufman, A.J., Cody, G., Farquhar, J., 2011. Evidence of magnetic isotope effects during thermochemical sulfate reduction. Proc. Natl. Acad. Sci. U.S.A. $108,17635-17638$.

Ohmoto, H., Lasaga, A.C., 1982. Kinetics of reactions between aqueous sulfates and sulfides in hydrothermal systems. Geochim. Cosmochim. Acta, 46(10), 1727-1745.

Ono, S., Wing, B., Johnston, D., Farquhar, J., Rumble, D., 2006. Mass-dependent fractionation of quadruple stable sulfur isotope system as a new tracer of sulfur biogeochemical cycles. Geochim. Cosmochim. Acta 70(9), 2238-2252.

Otake, T., Lasaga, A.C., Ohmoto, H., 2008. Ab initio calculations for equilibrium fractionations in multiple sulfur isotope systems. Chem. Geol. 249(3), 357-376.

632 Pokrovski, G.S., Dubessy, J., 2015. Stability and abundance of the trisulfur radical ion $\mathrm{S}_{3}^{-}$in hydrothermal fluids. Earth Planet. Sci. Lett. 411, 298-309.

634 Roussel, E.G., Cragg, B.A., Webster, G., Sass, H., Tang, X., Williams, A.S., Gorra, R., 635 Weightman, A.J., Parkes, R.J., 2015. Complex coupled metabolic and prokaryotic community responses to increasing temperatures in anaerobic marine sediments: critical

638 Sim, M.S., Bosak, T., Ono, S., 2011. Large sulfur isotope fractionation does not require 639 disproportionation. Science, 333(6038), 74-77. 
640 Steudel, R., Chivers, T., 2019. The role of polysulfide dianions and radical anions in the chemical, physical and biological sciences, including sulfur-based batteries. Chem. Soc. Rev. 48(12), 3279-3319.

643

Thomassot, E., O’Neil, J., Francis, D., Cartigny, P., Wing, B.A., 2015. Atmospheric record in the Hadean Eon from multiple sulfur isotope measurements in Nuvvuagittuq Greenstone Belt (Nunavik, Quebec). Proc. Natl. Acad. Sci. U.S.A. 112(3), 707-712.

Truche, L., Bazarkina, E.F., Barré, G., Thomassot, E., Berger, G., Dubessy, J., Robert, P., 2014. The role of $\mathrm{S}_{3}{ }^{-}$ion in thermochemical sulphate reduction: Geological and geochemical implications. Earth Planet. Sci. Lett. 396, 190-200.

Truche, L., Berger, G., Destrigneville, C., Pages, A., Guillaume, D., Giffaut, E. Jacquot, E., 2009. Experimental reduction of aqueous sulphate by hydrogen under hydrothermal conditions: implication for the nuclear waste storage. Geochim. Cosmochim. Acta, 73(16), 4824-4835.

Watanabe, Y., Farquhar, J., Ohmoto, H., 2009. Anomalous fractionations of sulfur isotopes during thermochemical sulfate reduction. Science 324, 370-373.

Werne, J.P., Hollander, D.J., Lyons, T.W., Damsté, J.S.S., 2004. Organic sulfur biogeochemistry: recent advances and future research directions. Geol. S. Am. S. 379, 135150.

Worden, R.H., Smalley, P.C., Fallick, A.E., 1997. Sulfur cycle in buried evaporites. Geology, $25,643-646$.

Wu, N., Farquhar, J., Strauss, H., 2014. $\delta^{34}$ S and $\Delta^{33}$ S records of Paleozoic seawater sulfate based on the analysis of carbonate associated sulfate. Earth Planet. Sci. Lett. 399, 44-51.

Yang, C., Hutcheon, I., Krouse, H.R., 2001. Fluid inclusion and stable isotopic studies of thermochemical sulphate reduction from Burnt Timber and Crossfield East gas fields in Alberta, Canada. Bull. Can. Petrol. Geol. 49(1), 149-164. 
Young, S.A., Loukola-Ruskeeniemi, K., Pratt, L.M., 2013. Reactions of hydrothermal solutions with organic matter in Paleoproterozoic black shales at Talvivaara, Finland: Evidence from multiple sulfur isotopes. Earth Planet. Sci. Lett. 367, 1-14.

Zerkle, A.L., Farquhar, J., Johnston, D.T., Cox, R.P., Canfield, D.E., 2009. Fractionation of multiple sulfur isotopes during phototrophic oxidation of sulfide and elemental sulfur by a green sulfur bacterium. Geochim. Cosmochim. Acta 73(2), 291-306.

\section{TABLE CAPTIONS}

Table 1. Multiple sulfur isotopes compositions of sulfur-bearing minerals from each studied site. Here, $\sigma$ corresponds to analytical uncertainty.

Table 2. ${ }^{33} \lambda$ and ${ }^{36} \lambda$ values calculated between sulfates and either associated elemental sulfur ( $\left.\mathrm{S}_{8}\right)$, pyrite, or chalcopyrite. When the ${ }^{33} \lambda$ value is between 0.5140 and 0.5170 , we assume that isotopic equilibrium was attained and therefore that the associated apparent equilibrium temperature, determined using the respective $\Delta^{34} \mathrm{~S}$ values and $\mathrm{SO}_{4}-\mathrm{S}_{8}$ (Eldridge et al., 2021) and $\mathrm{SO}_{4}-\mathrm{H}_{2} \mathrm{~S}$ (Eldridge et al., 2016) fractionation equations for each minerals pair, is valid. Note that isotopic composition of the sulfates is assumed to be constant because anhydrite is considered as an infinite reservoir.

\section{FIGURE CAPTIONS}

Fig. 1. Sampling locations on the simplified geological map of the Nappe des Gypses formation (Western French Alps; modified after Barré et al., 2020).

Figure 2: Typical sulfur-rich minerals observed in the Nappe des Gypses formation. (A) Pyrites in close association with anhydrite and white dolomite. (B, C) Crystals of elemental sulfur incorporated in gray dolomite "boudins" and diffuse elemental sulfur in the anhydrite facies. (D) Associated white dolomite, quartz, and pyrite association observed in carbonatesquartz-sulfides veins in micaschist layers. (E) Associated sulfides and elemental sulfur observed at the centimeter scale in the presence of micaschist at the Sollières l'Envers outcrop. 
690 (F, G) Respective plane and cross-polarized light images depicting the typical occurrence of 691 elemental sulfur in anhydrite. (H, I) Respective plane and cross-polarized light images depicting 692 direct association of pyrites with white micas. Abbreviations: Anh = anhydrite; Py = pyrite; S 693 = native sulfur; G-Dol = gray dolomite; $\mathrm{W}-\mathrm{Dol}=$ white dolomite; $\mathrm{Qtz}=$ quartz; $\mathrm{W}-\mathrm{Mca}=$ white 694 micas; $\mathrm{Fl}=$ fluorite.

695 Fig. 3. $\delta^{34} \mathrm{~S}$ values of sulfates, sulfides, and elemental sulfur at each studied site. The gray 696 shaded band shows $\delta^{34} \mathrm{~S}$ values typical of Carnian seawater (Claypool et al., 1980; Crockford 697 et al., 2019). Error bars are smaller than the symbol sizes.

$698 \quad$ Fig. 4. $\Delta^{33}$ S vs. $\delta^{34}$ S diagrams for sulfates, sulfides, and elemental sulfur from each studied 699 site. Outcrops are plotted from south to north: (A) Névache, (B) Bramans, (C) Ambin stream, 700 (D) Sollières l'Envers, (E) Mont-Cenis Lake, and (F) Tignes. For each site, the mass 701 fractionation exponent near 0.515 (i.e., for samples at isotopic equilibrium) between sulfates 702

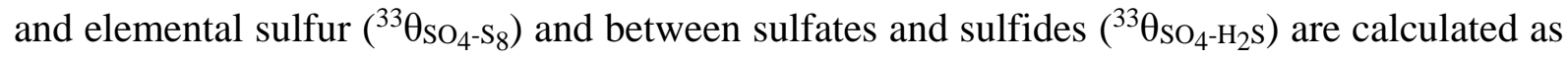
well as the associated vector between sulfate and elemental sulfur (green arrow) and between 704 sulfate and sulfide (red arrow). In these cases, isotopic equilibrium is confirmed (see section 705 5.4) and the associated equilibrium temperature is determined using the respective $\Delta^{34} \mathrm{~S}$ values and $\mathrm{SO}_{4}-\mathrm{S}_{8(\mathrm{aq})}$ (green; Eldridge et al., 2021) or $\mathrm{SO}_{4}-\mathrm{H}_{2} \mathrm{~S}_{(\mathrm{aq})}$ (red; Eldridge et al., 2016) fractionation equations. Two-component mixing curves (yellow dashed curves) are calculated 708 between the most extreme sulfate and elemental sulfur compositions. In (A) and (B), the gray 709 dashed curve is the mixing curve between sulfates and a theoretical organic sulfur reservoir 710 (estimated at $\delta^{34} \mathrm{~S}=-30 \%$ and the $\Delta^{33} \mathrm{~S}$ value determined using ${ }^{33} \lambda=0.5152$ ). Errors bars 711 represent $1 \sigma$ for dual-inlet mass-spectrometry measurements. Measurement errors on $\delta^{34} \mathrm{~S}$ are 712 smaller than the symbol sizes.

713 Fig. 5. Plots of ${ }^{33} \lambda$ vs. temperature between sulfates and either elemental sulfur (diamonds), 714 pyrite (squares), or chalcopyrite (triangles). For each mineral pair, temperatures are estimated 
715 from the respective $\Delta^{34} \mathrm{~S}$ values and $\mathrm{SO}_{4}-\mathrm{S}_{8(\mathrm{aq})}$ (Eldridge et al., 2021) or $\mathrm{SO}_{4}-\mathrm{H}_{2} \mathrm{~S}_{(\mathrm{aq})}$ (Eldridge et al., 2016) fractionation equations. Curves indicate the evolution of ${ }^{33} \lambda$ as a function of temperature for different sulfur species relative to sulfates from theoretical calculations $\left(\mathrm{CS}_{2 \mathrm{aq}}\right.$ is from Otake et al., 2008; $\mathrm{H}_{2} \mathrm{~S}_{\text {aq }}$ and $\mathrm{SO}_{3}{ }^{2-}$ from Eldridge et al., 2016; $\mathrm{S}_{8}, \mathrm{~S}_{3}{ }^{-}$and $\mathrm{S}_{n}{ }^{2-}$ from Eldridge et al., 2021). Errors represent $1 \sigma$ for dual-inlet mass-spectrometry measurements.

Fig. 6. Elemental sulfur melting curve (black curve, shaded area indicates experimental errors; from Crapanzano, 2005). For comparison, the $P-T$ path of the Nappe des Gypses formation (blue arrow and squares; Barré et al., 2020) and the elemental sulfur precipitation temperature determined herein (yellow shaded area; see section 5.4 for details) are shown. The Nappe des Gypses $P$ - $T$ path crosses the elemental sulfur melting curve at conditions consistent with the temperature range calculated from the isotopic compositions of our samples, indicating that all the elemental sulfur precipitated just after the D2-D3 tectonic transition during the exhumation of the Nappe des Gypses.

Fig. 7. $\Delta^{33} \mathrm{~S}$ vs. $\Delta^{36} \mathrm{~S}$ diagrams for sulfates, sulfides, and elemental sulfur from each studied site. Outcrops are plotted from south to north: (A) Névache, (B) Bramans, (C) Ambin stream, (D) Sollières l'Envers, (E) Mont-Cenis Lake, and (F) Tignes. Two-component mixing curves

731 (yellow dashed curves) are calculated between the most extreme sulfate and elemental sulfur 732 compositions. In (A) and (B), the gray dashed curve is the mixing curve between sulfates and 733 a theoretical organic sulfur reservoir with estimated $\Delta^{33} S$ and $\Delta^{36} S$ values determined using ${ }^{33} \lambda$ $734=0.5152$ and ${ }^{36} \lambda=1.89$, respectively. The mass-dependent fractionation line (dashed black line 735 of slope -6.9 ; Ono et al., 2006) is also shown for comparison. Errors bars represent $1 \sigma$ for dual736 inlet mass-spectrometry measurements.

737 Fig. 8. Schematic summary of the TSR reaction pathway and associated isotopic 738 fractionations. (Left) The initial thermodynamic state (Truche et al., 2014), isotopic signatures 739 (this study), and relative proportions (Barré et al., 2017) of sulfates and elemental sulfur 
740 reservoirs in the fluid during TSR. (Right) Three possibilities for generating the observed 741 elemental sulfur and sulfide compositions. (1) When no metal is present in the system, the 742 combination of polysulfides leads to elemental sulfur precipitation at isotopic equilibrium with 743 the sulfate; the resulting isotopic signature is temperature dependent. (2) When a large amount 744 of metal is released into the system, all reduced sulfur species $\left(\mathrm{H}_{2} \mathrm{~S}\right.$ and $\left.\mathrm{S}_{n}{ }^{2-}\right)$ precipitate as 745 sulfide at isotopic equilibrium with sulfate and experience a temperature-dependent isotopic 746 fractionation. (3) When only a small amount of metal (i.e., less than the reduced sulfur species) 747 is released into the system, only some of the $\mathrm{H}_{2} \mathrm{~S}$ precipitates as sulfide. The resulting 748 disequilibrium isotopic composition of the sulfides corresponds to the mixing between $33 \%$ 749 elemental sulfur (i.e., polysulfides) with $67 \%$ sulfate. The similarity of the calculated and 750 measured sulfide isotopic compositions (bottom right) confirms that the disequilibrium sulfides 751 precipitated from the mixing of sulfates and polysulfides. 


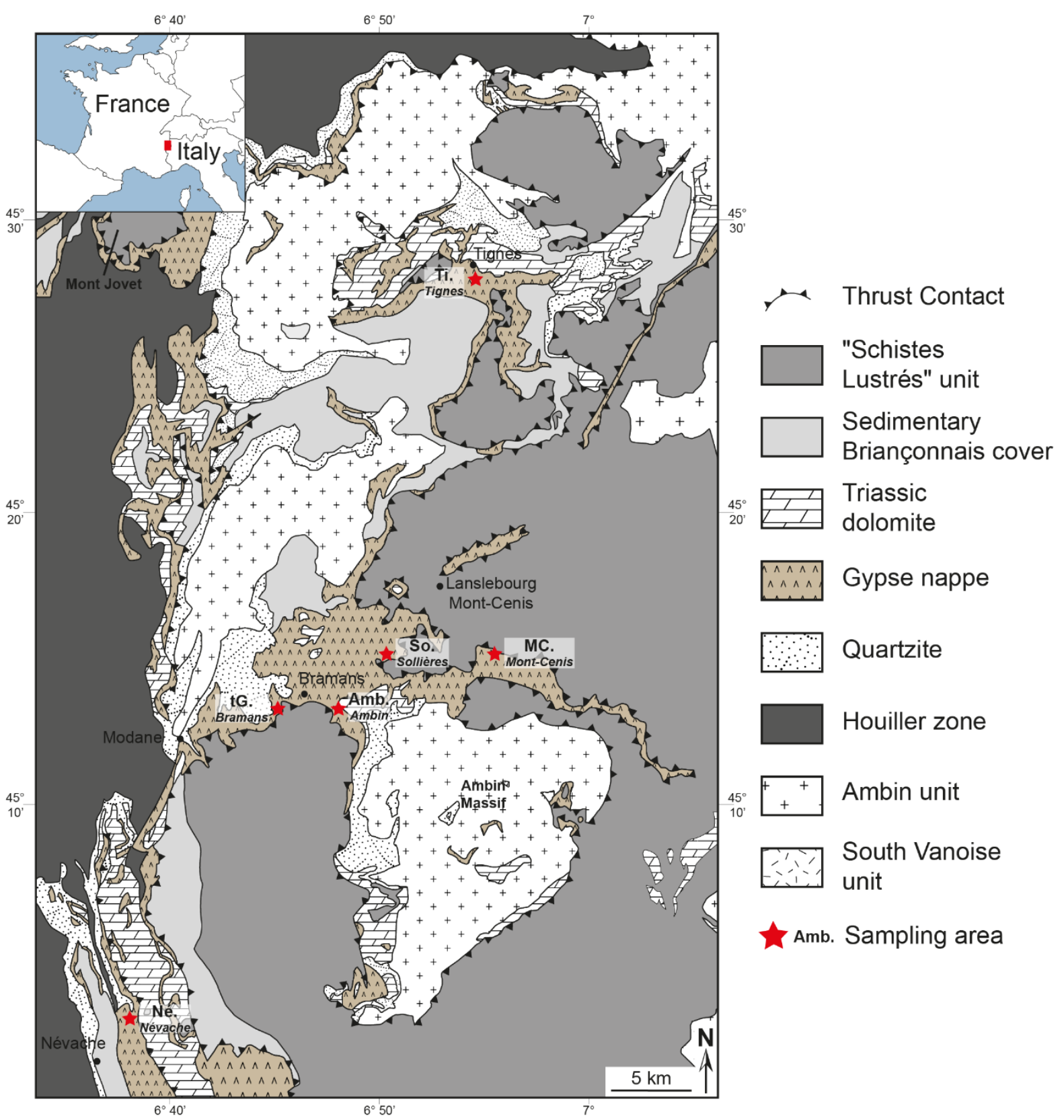


Figure 2

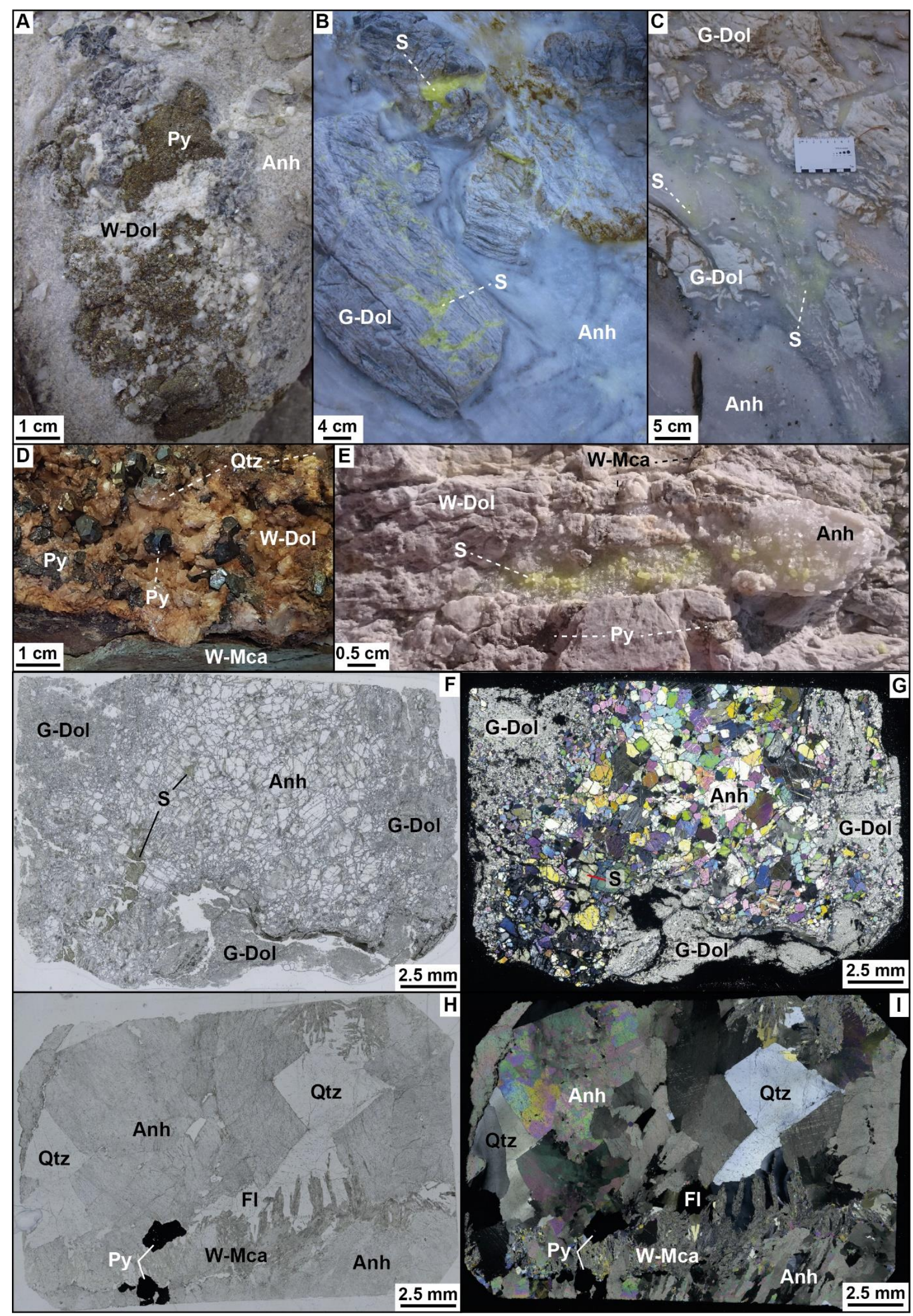


Figure 3

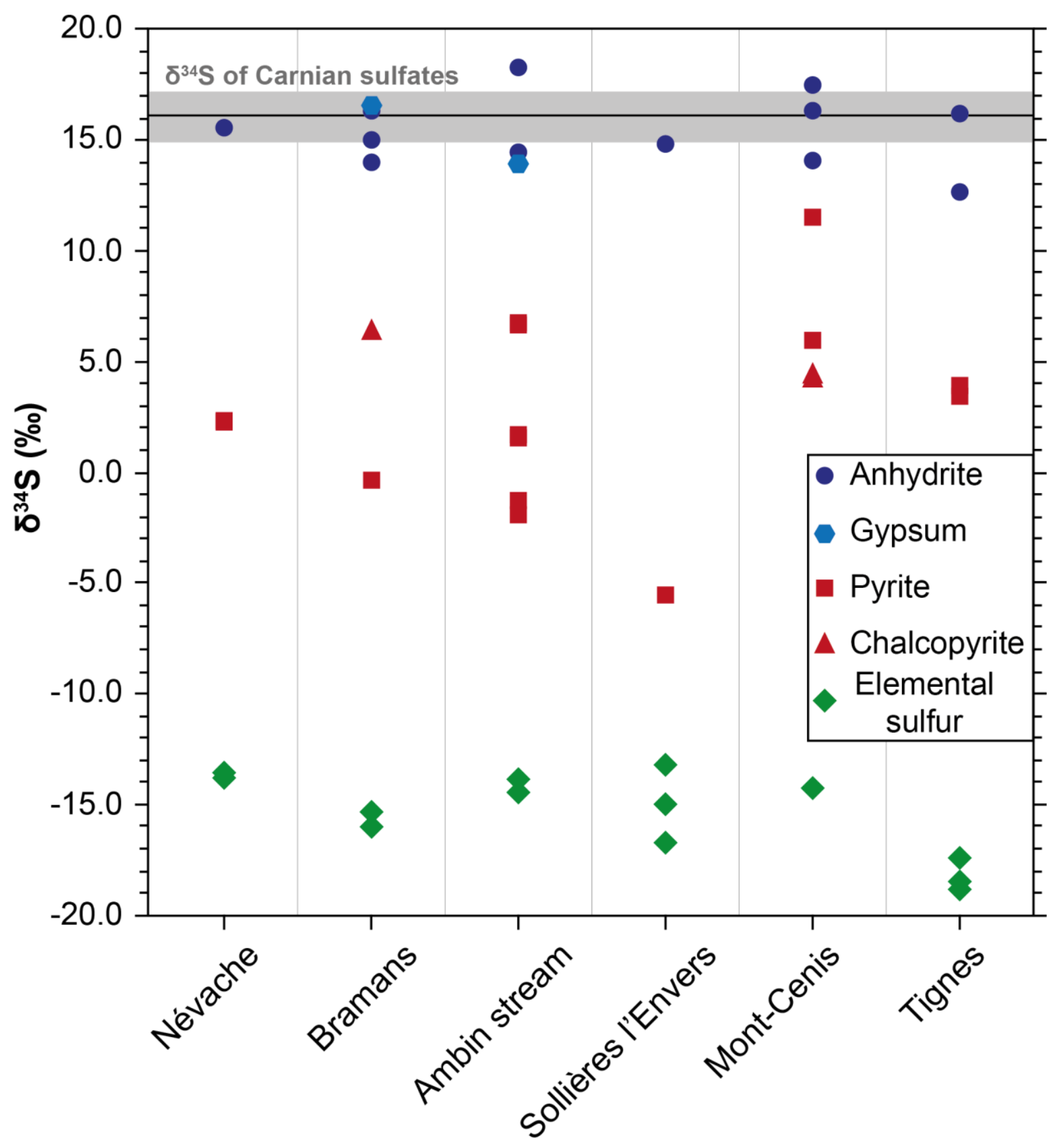

760 
Figure 4
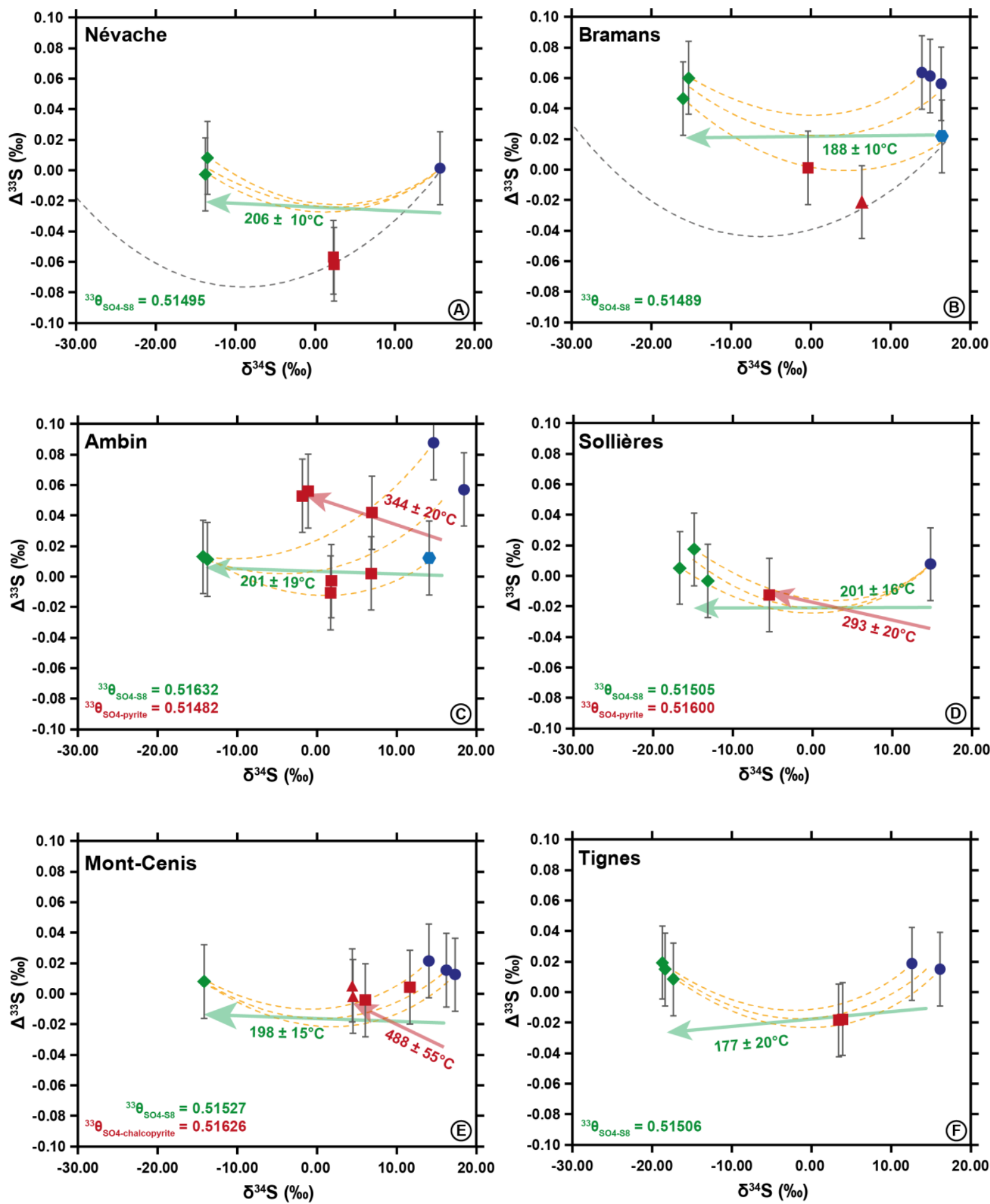

\begin{tabular}{|llll|}
\hline I Anhydrite & I Pyrite & I Elemental sulfur & $\ddots, i \begin{array}{c}\text { Theoretical } \\
\text { mixing curve }\end{array}$ \\
I Gypsum & I Chalcopyrite & Mixing curve & $\begin{array}{c}\text { Isotopic equilibrium } \\
\text { vector }\end{array}$ \\
\hline
\end{tabular}


Figure 5

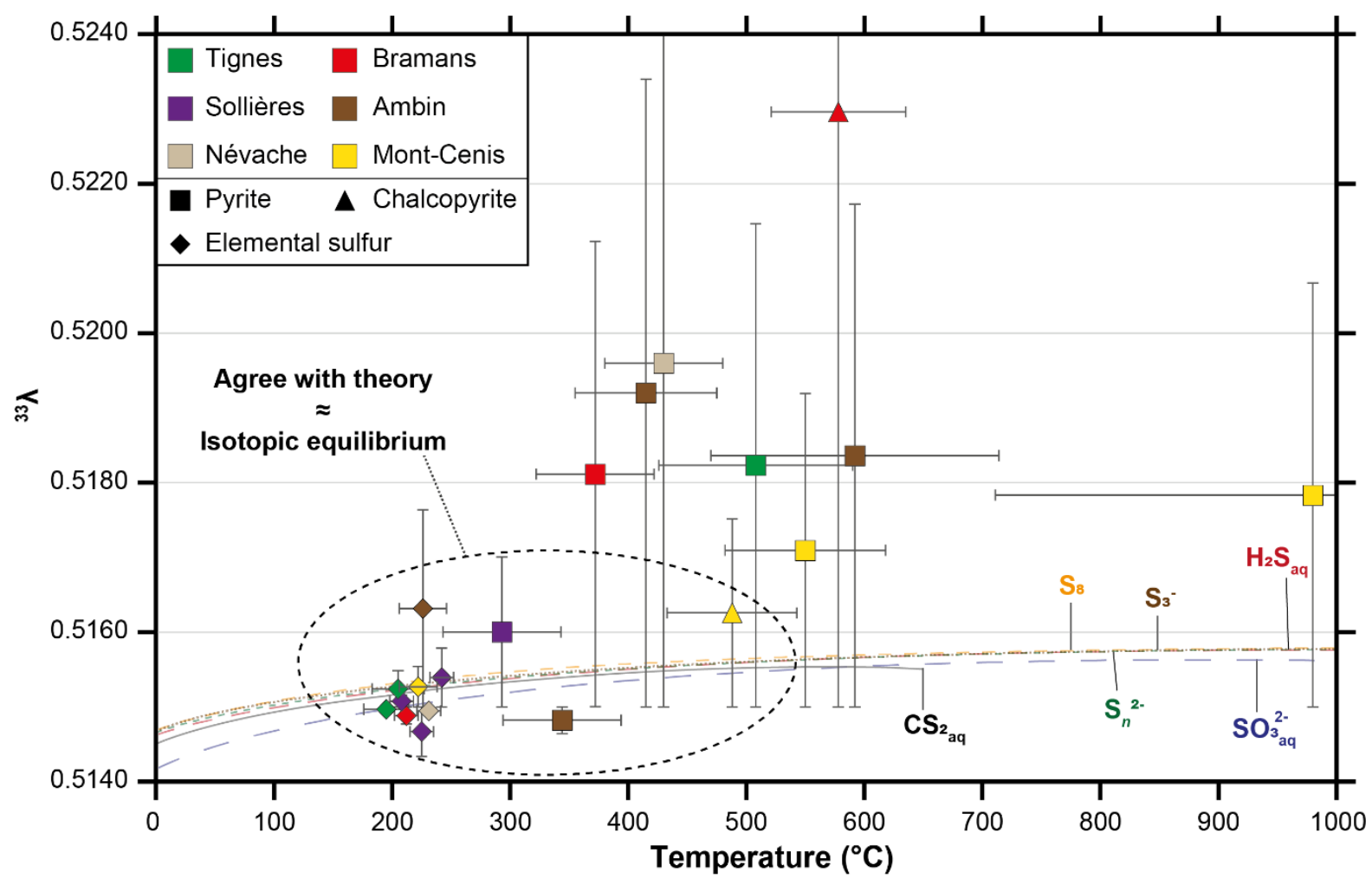


Figure 6

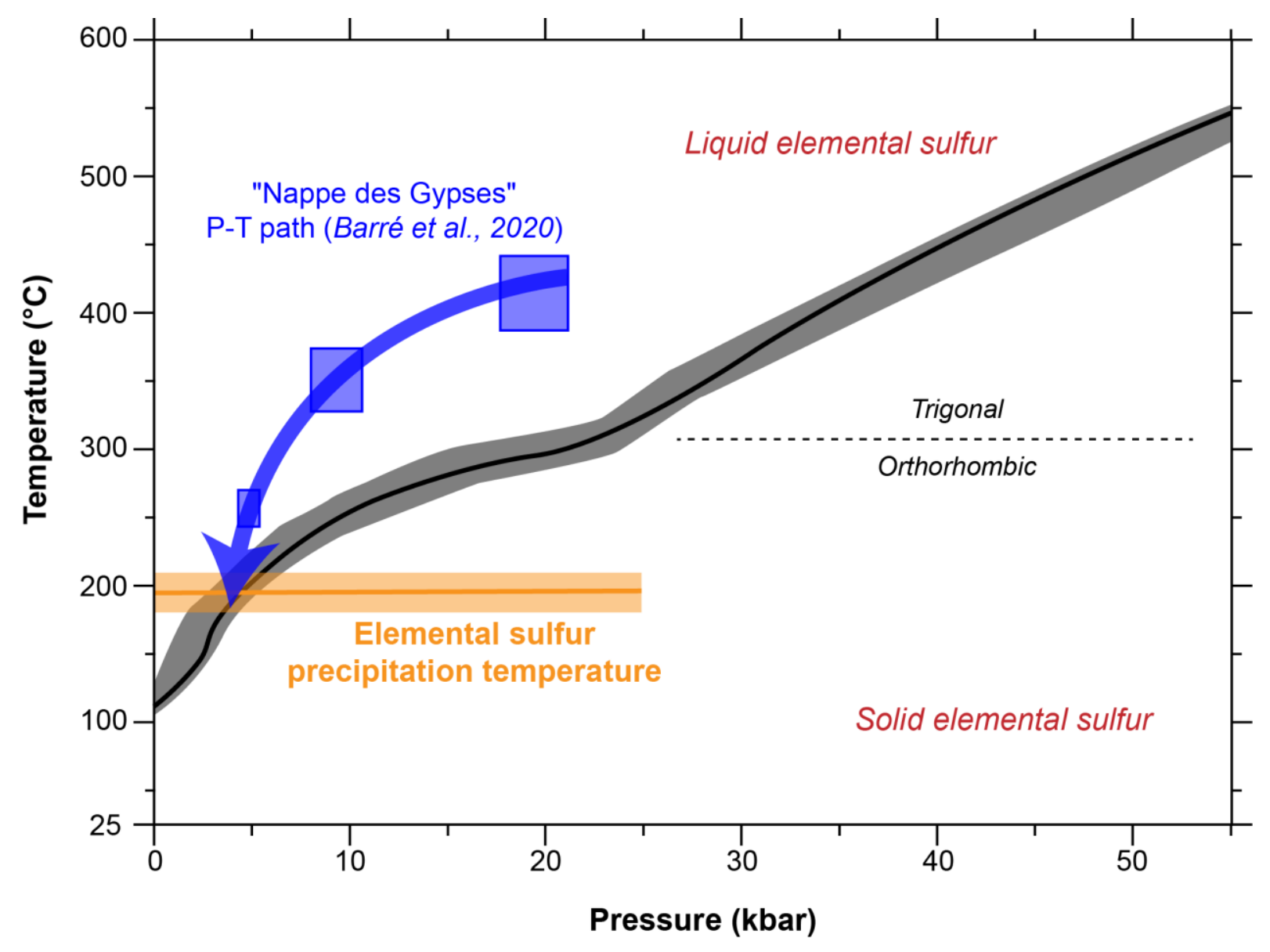


Figure 7
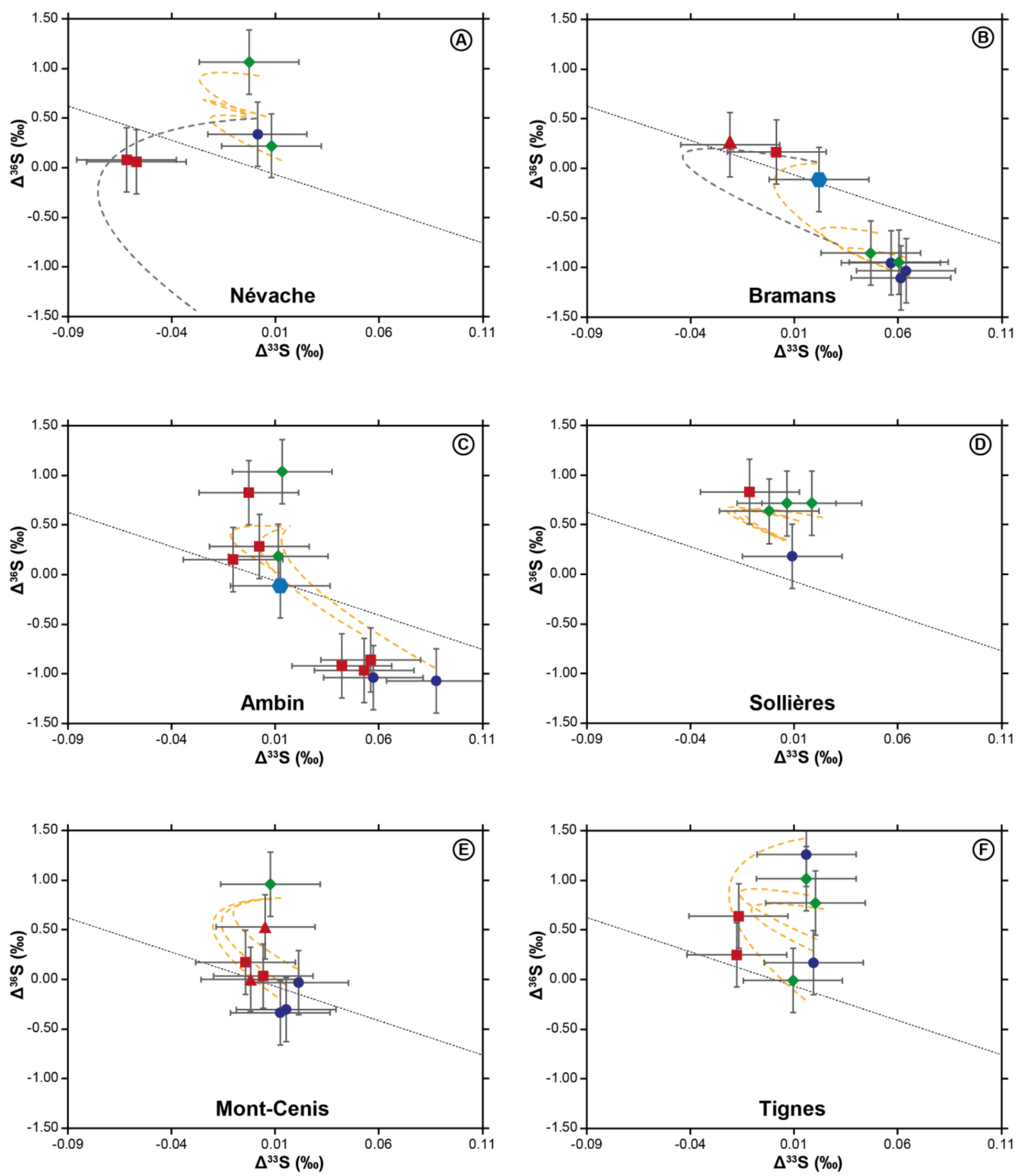


\section{Thermochemical Sulfate Reduction}

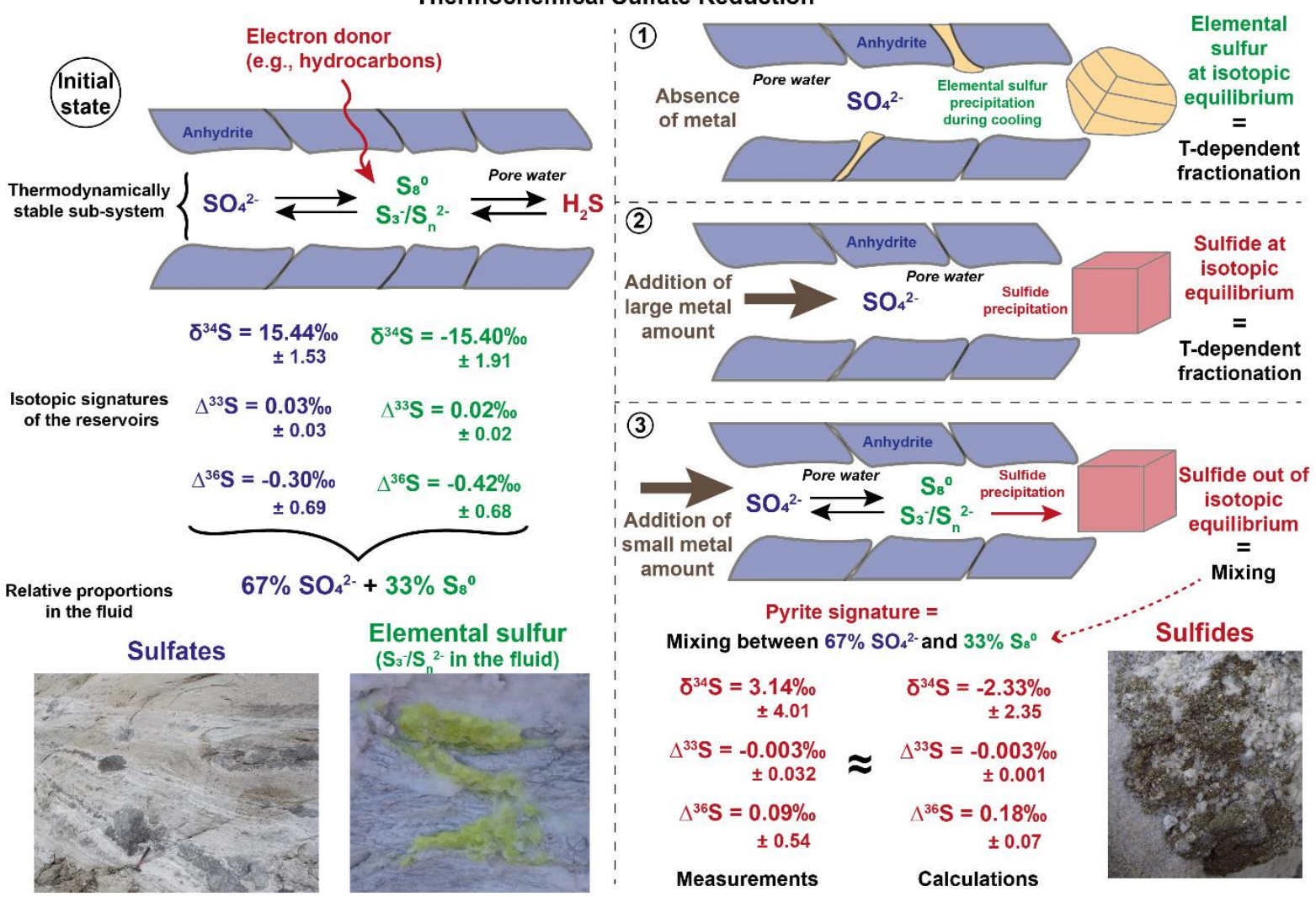


Table 1

\begin{tabular}{|c|c|c|c|c|c|c|c|c|c|}
\hline Sample & Mineral & $\delta^{33} S(\%)$ & $\pm \sigma$ & $\delta^{34} \mathrm{~S}(\%)$ & $\pm \sigma$ & $\delta^{36} \mathrm{~S}(\% 0)$ & $\pm \sigma$ & $\Delta^{33} \mathrm{~S}(\%)$ & $\Delta^{36} \mathbf{S}(\% 0)$ \\
\hline \multicolumn{10}{|l|}{ Névache } \\
\hline Né.1.2 & Anhydrite & 8.02 & 0.012 & 15.64 & 0.007 & 30.26 & 0.030 & 0.00 & 0.34 \\
\hline Né.3.1 & Pyrite & 1.15 & 0.008 & 2.34 & 0.006 & 4.52 & 0.092 & -0.06 & 0.06 \\
\hline Né.3.2 & Pyrite & 1.15 & 0.010 & 2.36 & 0.005 & 4.56 & 0.083 & -0.06 & 0.08 \\
\hline Né.S8.1 & Elemental sulfur & -7.09 & 0.013 & -13.71 & 0.008 & -24.82 & 0.255 & 0.00 & 1.06 \\
\hline Né.S8.2 & Elemental sulfur & -6.97 & 0.008 & -13.51 & 0.006 & -25.29 & 0.070 & 0.01 & 0.22 \\
\hline \multicolumn{10}{|l|}{ Bramans } \\
\hline tG.1.1 & Anhydrite & 8.49 & 0.019 & 16.43 & 0.035 & 30.50 & 0.115 & 0.06 & -0.95 \\
\hline tG.1.2 & Anhydrite & 7.80 & 0.014 & 15.08 & 0.011 & 27.74 & 0.091 & 0.06 & -1.11 \\
\hline tG.11 & Anhydrite & 7.29 & 0.012 & 14.07 & 0.012 & 25.88 & 0.075 & 0.06 & -1.04 \\
\hline tG. 16.1 & Gypsum & 8.52 & 0.006 & 16.57 & 0.012 & 31.60 & 0.162 & 0.02 & -0.11 \\
\hline tG.12.1 & Pyrite & -0.15 & 0.009 & -0.30 & 0.002 & -0.41 & 0.128 & 0.00 & 0.16 \\
\hline tG.16.S2 & Chalcopyrite & 3.31 & 0.013 & 6.47 & 0.006 & 12.57 & 0.132 & -0.02 & 0.23 \\
\hline tG.S0.1 & Elemental sulfur & -8.22 & 0.011 & -16.00 & 0.009 & -31.03 & 0.111 & 0.05 & -0.85 \\
\hline tG.S0.2 & Elemental sulfur & -7.83 & 0.013 & -15.26 & 0.004 & -29.74 & 0.030 & 0.06 & -0.95 \\
\hline \multicolumn{10}{|l|}{ Ambin } \\
\hline Amb.4.SO.1 & Anhydrite & 7.54 & 0.036 & 14.52 & 0.041 & 26.70 & 0.178 & 0.09 & -1.07 \\
\hline Amb.4.SO.2 & Anhydrite & 9.49 & 0.012 & 18.39 & 0.011 & 34.19 & 0.064 & 0.06 & -1.04 \\
\hline Amb.1 & Gypsum & 7.19 & 0.014 & 13.99 & 0.004 & 26.63 & 0.084 & 0.01 & -0.11 \\
\hline Amb.4.S2.1 & Pyrite & -0.91 & 0.006 & -1.88 & 0.006 & -4.53 & 0.092 & 0.05 & -0.97 \\
\hline Amb.4.S2.2 & Pyrite & -0.55 & 0.015 & -1.18 & 0.022 & -3.10 & 0.098 & 0.06 & -0.86 \\
\hline Amb.2.1 & Pyrite & 3.56 & 0.017 & 6.84 & 0.017 & 12.12 & 0.105 & 0.04 & -0.92 \\
\hline Amb.2.2 & Pyrite & 3.48 & 0.009 & 6.77 & 0.002 & 13.17 & 0.089 & 0.00 & 0.28 \\
\hline Amb.B.S.1 & Pyrite & 0.91 & 0.009 & 1.77 & 0.006 & 4.18 & 0.358 & 0.00 & 0.82 \\
\hline Amb.B.S.2 & Pyrite & 0.82 & 0.005 & 1.62 & 0.003 & 3.23 & 0.066 & -0.01 & 0.15 \\
\hline Amb.3.1 & Elemental sulfur & -7.40 & 0.007 & -14.34 & 0.007 & -26.03 & 0.324 & 0.01 & 1.03 \\
\hline Amb.3.2 & Elemental sulfur & -7.10 & 0.010 & -13.77 & 0.005 & -25.82 & 0.133 & 0.01 & 0.18 \\
\hline \multicolumn{10}{|l|}{ Sollières } \\
\hline$\alpha$ So.3 & Anhydrite & 7.66 & 0.006 & 14.91 & 0.008 & 28.70 & 0.217 & 0.01 & 0.18 \\
\hline$\alpha$ So. 2.2 & Pyrite & -2.82 & 0.008 & -5.44 & 0.011 & -9.49 & 0.273 & -0.01 & 0.82 \\
\hline So.D.1.S8 & Elemental sulfur & -8.64 & 0.006 & -16.72 & 0.005 & -30.82 & 0.217 & 0.01 & 0.71 \\
\hline$\alpha$ So. 2.3 & Elemental sulfur & -6.80 & 0.011 & -13.17 & 0.003 & -24.24 & 0.191 & 0.00 & 0.63 \\
\hline So. 4 & Elemental sulfur & -7.68 & 0.010 & -14.90 & 0.002 & -27.42 & 0.204 & 0.02 & 0.71 \\
\hline \multicolumn{10}{|l|}{ Mont-Cenis } \\
\hline MC.4.SO.1 & Anhydrite & 7.21 & 0.011 & 14.00 & 0.004 & 26.74 & 0.111 & 0.02 & -0.03 \\
\hline MC.4.SO.2 & Anhydrite & 8.88 & 0.011 & 17.28 & 0.005 & 32.76 & 0.074 & 0.01 & -0.33 \\
\hline MC. 2 & Anhydrite & 8.33 & 0.008 & 16.20 & 0.008 & 30.71 & 0.122 & 0.02 & -0.30 \\
\hline MC.3.1.1 & Pyrite & 3.10 & 0.005 & 6.04 & 0.006 & 11.68 & 0.076 & 0.00 & 0.17 \\
\hline MC.3.1.4 & Pyrite & 5.96 & 0.005 & 11.60 & 0.004 & 22.20 & 0.050 & 0.00 & 0.04 \\
\hline MC.3.1.2 & Chalcopyrite & 2.29 & 0.007 & 4.45 & 0.004 & 8.47 & 0.111 & 0.00 & 0.00 \\
\hline MC.3.1.3 & Chalcopyrite & 2.24 & 0.012 & 4.34 & 0.005 & 8.79 & 0.192 & 0.01 & 0.53 \\
\hline MC.4.S8 & Elemental sulfur & -7.36 & 0.010 & -14.25 & 0.004 & -25.95 & 0.220 & 0.01 & 0.96 \\
\hline \multicolumn{10}{|l|}{ Tignes } \\
\hline Ti.1.SO & Anhydrite & 8.36 & 0.007 & 16.27 & 0.006 & 32.40 & 0.093 & 0.02 & 1.26 \\
\hline Ti.2.SO & Anhydrite & 6.56 & 0.015 & 12.74 & 0.006 & 24.52 & 0.052 & 0.02 & 0.17 \\
\hline Ti.3.1 & Pyrite & 2.06 & 0.007 & 4.03 & 0.010 & 8.31 & 0.171 & -0.02 & 0.64 \\
\hline Ti.3.2 & Pyrite & 1.77 & 0.010 & 3.48 & 0.008 & 6.87 & 0.081 & -0.02 & 0.25 \\
\hline Ti.1.S8.1 & Elemental sulfur & -9.52 & 0.009 & -18.43 & 0.006 & -33.71 & 0.230 & 0.02 & 1.01 \\
\hline Ti.1.S8.2 & Elemental sulfur & -9.72 & 0.005 & -18.82 & 0.004 & -34.69 & 0.175 & 0.02 & 0.77 \\
\hline Ti.2.S8 & Elemental sulfur & -8.98 & 0.011 & -17.39 & 0.005 & -32.79 & 0.123 & 0.01 & -0.01 \\
\hline
\end{tabular}


Table 2

\begin{tabular}{|c|c|c|c|c|c|c|c|c|c|}
\hline Locality & Sample & Mineral & ${ }^{33} \lambda$ & $1 \sigma$ & ${ }^{36} \lambda$ & $1 \sigma$ & $\mathbf{T}^{\circ} \mathbf{C}$ & $1 \sigma$ & $\begin{array}{c}\text { Valid } \\
\text { temperature? }\end{array}$ \\
\hline \multirow[b]{2}{*}{ Névache } & Né.3 & Pyrite & 0.51960 & 0.00460 & 1.91973 & 0.02973 & 430 & 20 & No \\
\hline & Né.S8 & $\begin{array}{l}\text { Elemental } \\
\text { sulfur }\end{array}$ & 0.51495 & 0.00005 & 1.88873 & 0.00134 & 206 & 10 & Yes \\
\hline \multirow{3}{*}{ Bramans } & tG.12.1 & Pyrite & 0.51812 & 0.00311 & 1.84051 & 0.04949 & 372 & 20 & No \\
\hline & tG.16.S2 & Chalcopyrite & 0.52296 & 0.00796 & 1.78740 & 0.10260 & 578 & 57 & No \\
\hline & tG.SO & $\begin{array}{l}\text { Elemental } \\
\text { sulfur }\end{array}$ & 0.51489 & 0.00012 & 1.90484 & 0.01484 & 188 & 10 & Yes \\
\hline \multirow{4}{*}{ Ambin } & Amb.4.S2 & Pyrite & 0.51482 & 0.00018 & 1.91167 & 0.02167 & 344 & 20 & Yes \\
\hline & Amb. 2 & Pyrite & 0.51836 & 0.00336 & 1.85402 & 0.03599 & 592 & 122 & No \\
\hline & Amb.B.S & Pyrite & 0.51920 & 0.00420 & 1.81325 & 0.07675 & 415 & 60 & No \\
\hline & Amb. 3 & $\begin{array}{l}\text { Elemental } \\
\text { sulfur }\end{array}$ & 0.51632 & 0.00132 & 1.85488 & 0.03512 & 201 & 19 & Yes \\
\hline \multirow{4}{*}{ Sollières } & $\alpha$ So. 2.2 & Pyrite & 0.51600 & 0.00100 & 1.86761 & 0.02239 & 293 & 20 & Yes \\
\hline & So.D.1.S8 & $\begin{array}{l}\text { Elemental } \\
\text { sulfur }\end{array}$ & 0.51508 & 0.00008 & 1.88250 & 0.00751 & 185 & 10 & Yes \\
\hline & $\alpha$ So.2.3 & $\begin{array}{l}\text { Elemental } \\
\text { sulfur }\end{array}$ & 0.51539 & 0.00039 & 1.88320 & 0.00682 & 217 & 10 & Yes \\
\hline & So.4 & $\begin{array}{l}\text { Elemental } \\
\text { sulfur }\end{array}$ & 0.51467 & 0.00033 & 1.88139 & 0.00862 & 200 & 10 & Yes \\
\hline \multirow{4}{*}{$\begin{array}{l}\text { Mont- } \\
\text { Cenis }\end{array}$} & MC.3.1.1 & Pyrite & 0.51710 & 0.00210 & 1.86016 & 0.02984 & 550 & 68 & No \\
\hline & MC.3.1.4 & Pyrite & 0.51783 & 0.00283 & 1.84000 & 0.05000 & 980 & 269 & No \\
\hline & MC.3.2 & Chalcopyrite & 0.51626 & 0.00126 & 1.85803 & 0.03197 & 488 & 55 & Yes \\
\hline & MC.4.S8 & $\begin{array}{l}\text { Elemental } \\
\text { sulfur }\end{array}$ & 0.51527 & 0.00027 & 1.86009 & 0.02991 & 198 & 15 & Yes \\
\hline \multirow{3}{*}{ Tignes } & Ti.3 & Pyrite & 0.51823 & 0.00323 & 1.92388 & 0.03388 & 508 & 82 & No \\
\hline & Ti.1.S8 & $\begin{array}{l}\text { Elemental } \\
\text { sulfur }\end{array}$ & 0.51497 & 0.00004 & 1.89314 & 0.00317 & 172 & 18 & Yes \\
\hline & Ti.2.S8 & $\begin{array}{l}\text { Elemental } \\
\text { sulfur }\end{array}$ & 0.51524 & 0.00024 & 1.92214 & 0.03215 & 182 & 21 & Yes \\
\hline
\end{tabular}


